
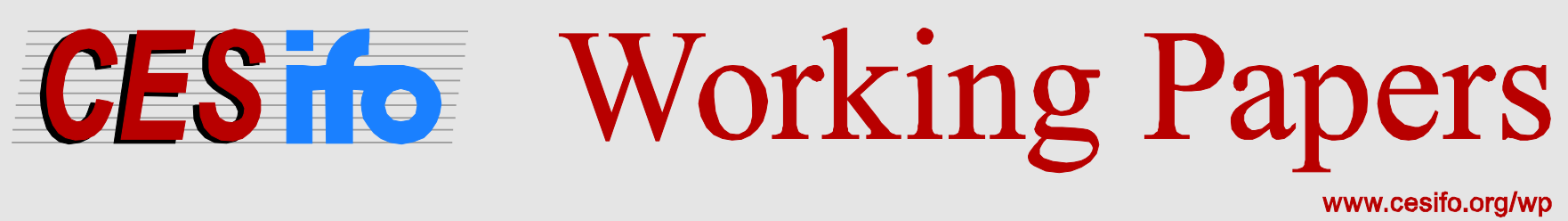

\title{
Vertical Effects of Fiscal Rules The Swiss Experience
}

\author{
Heiko T. Burret \\ Lars P. Feld
}

CESIFO WORKING PAPER NO. 5043

CATEgory 2: Public CHOICE

OCTOBER 2014

An electronic version of the paper may be downloaded

- from the SSRN website:

- from the RePEc website:

- from the CESifo website:

wWw.SSRN.com

www.RePEc.org

www.CESifo-group.org/wp

\section{CESifo}




\title{
Vertical Effects of Fiscal Rules The Swiss Experience
}

\begin{abstract}
Formal fiscal rules have been introduced in many countries throughout the world. While most studies focus on intra-jurisdictional effects of fiscal rules, vertical impacts on the finances of other levels of governments have yet to be explored thoroughly. The paper investigates the influence of Swiss cantonal debt brakes on municipal finances during the years 1980-2011 by examining cantonal aggregated and disaggregated local data. A Difference-in-Differences estimation (two-way fixed effects) provides little evidence that budget constraints at the cantonal level affect municipal finances and fiscal decentralization, respectively.
\end{abstract}

JEL-Code: H600, H770, H740, H720.

Keywords: fiscal rules, vertical effects, fiscal shocks, decentralization, sub-national finances.

Heiko T. Burret

Walter Eucken Institute

Goethestr. 10

Germany - 79100 Freiburg

burret@eucken.de
Lars $P$. Feld

Walter Eucken Institute \& Albert-Ludwigs-University Freiburg

Goethestr. 10

Germany - 79100 Freiburg

feld@eucken.de

October 2014

We would like to thank Gerrit Gonschorek and Leonardo Palhuca for valuable research assistance and Simon Luechinger and Christoph Schaltegger for providing us with cantonal data on realized and forecasted revenue and expenditure, respectively. We are grateful to Martina Neuhaus from the Swiss Federal Department of Finance for providing us with the best data available on local finances. 


\section{INTRODUCTION}

National and sub-national fiscal rules are meanwhile widespread hoping that they reduce incentives to overspend and thus ensure fiscal sustainability of economies. Still, politicians are tempted to circumvent the constraints in order to regain fiscal discretion. Unintended consequences of fiscal rules have been primarily discussed with respect to window-dressing and creative accounting. Measures such as accumulation of tax arrears, reclassification of expenditures, off-budget activities and the use of non-restricted debt instruments may help to disguise public deficits. ${ }^{1}$ Consequently, political decision-makers follow the letter of the rule, but only temporarily embellish the targeted headline indicators hardly improving the underlying fiscal position.

In addition to such intra-jurisdictional effects, fiscal rules on a higher government level may influence lower government finances although the latter are not directly covered by the rule. Unlike accounting gimmicks, those vertical effects might change recurring costs on the upper government level and affect the extent of fiscal decentralization. Various vertical transmission channels can be conceived (Figure 1): Higher-level governments might (1) award unfunded mandates to lower levels or (2) manipulate transfers. Conversely, fiscal constraints might spill over to other jurisdictions, if the upper level of government has responsibility for lower level finances with the result that the upper level government (3) restricts lower level finances in order to hedge the risk of higher transfers or future bailouts. This solicitude might have been less pronounced prior to the introduction of a fiscal rule, as the upper level could finance (bailout) transfers by incurring higher debt. Alternatively, vertical effects could proceed rather informally. If fiscal rules prevent upper government levels from responding to citizen demands, citizens might (4) shift their demands to lower levels of governments with the result that lowerlevel finances are burdened (Nice, 1991). However, it is also possible that citizens are (5) more willing to devolve responsibilities to the upper level of government believing that overspending at the upper government level is effectively controlled for by budget constraints. Thus, the fiscal burden of lower government tiers is reduced. Finally, fewer resources at the constrained higher level of government may (6) restrict budgets of lower levels of governments. ${ }^{2}$

\footnotetext{
${ }^{1}$ For various guises of fiscal gimmickry refer to, e.g., Irwin (2012), Koen and van den Noord (2005).

${ }^{2}$ For Channel (5) and (6), see Funk and Gathmann (2011) on the vertical effects of direct democratic institutions.
} 
Figure 1 Vertical transmission channels of budget constraints

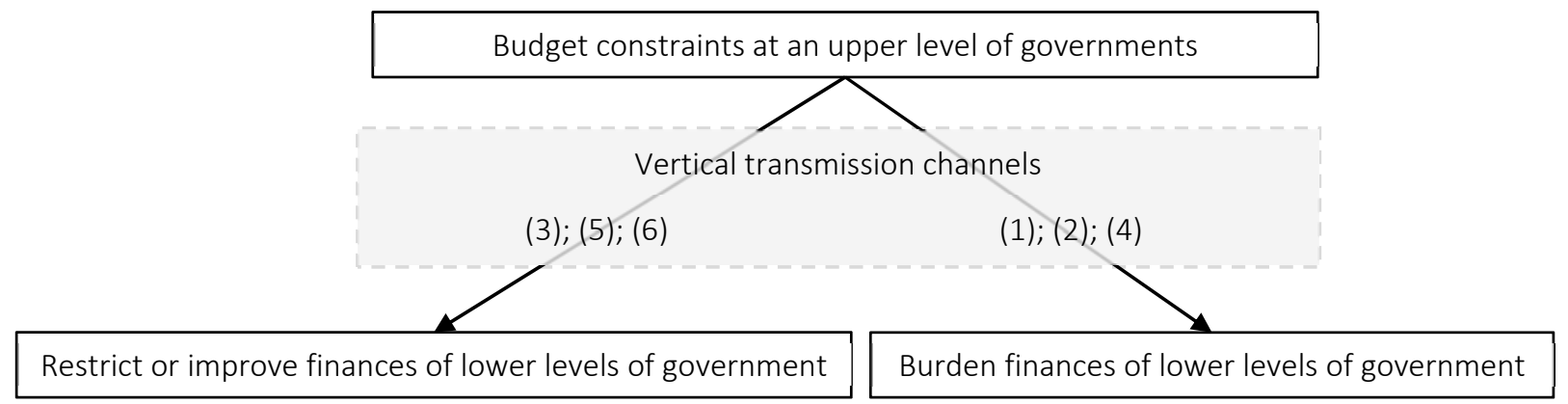

Although little research exists on vertical effects of fiscal rules, German municipalities alleged that the new budget constraints at the state level (Laender) would burden their finances (see Lenk et al., 2012; German Association of Cities, 2011). ${ }^{3}$ Swiss municipalities expressed similar concerns that, e.g., the canton of Zurich consolidates its budget on their back (NZZ, 2004). Since 2001, the cantonal pressure to consolidate is supported by a fiscal rule requiring a balanced budget within five years (Art. 123: 2 Constitution of Zurich). In fact, municipal secretaries (Gemeindeschreiber) claim that the canton of Zurich has indeed shifted fiscal burden to the local level (Steiner et al., 2012).

Against this background, this paper analyzes the influence of cantonal debt brakes on local finances in Switzerland by exploiting a sample of (almost) all municipalities aggregated at the cantonal level (1980-2011) and a sample of disaggregated data of the 139 largest cities (19822007). A two-way fixed effects analysis, which can be interpreted to be equivalent to a generalized Difference-in-Differences estimation, provides little evidence that budget constraints at the cantonal level significantly affect local finances or decentralization.

The remainder of this paper is organized as follows: Section 2 reviews empirical studies. Section 3 presents the Swiss institutional framework and finishes with testable hypotheses. The data and empirical strategy are presented in Section 4. The baseline results are reported in Section 5 and the robustness checks in Section 6. Section 7, finally, discusses implications of the main findings and offers concluding remarks.

\footnotetext{
${ }^{3}$ Petra Roth (then President of the German Association of Cities and mayor of Frankfurt am Main) stated in 2011 that the communities needed a protective shield, which prevented the German states (Laender), in complying with their debt brakes, from shifting public debt to their municipalities thus deteriorating local finances.
} 


\section{LITERATURE REVIEW}

The first empirical studies on the effects of sub-national fiscal rules on budget outcomes have presumably been conducted in the late 1960s for the US (e.g., Mitchell, 1967; Pogue, 1970). While a large number of studies on the spending and revenue effects of fiscal rules followed, more recent studies provide evidence that strong budget limitations reduce budget deficits and public debt, i.e., support fiscal discipline among US states (for a survey see Burret and Feld, 2014). Similar evidence exists for other countries, such as Canada (e.g. Imbeau and Tellier, 2004), Latin America (e.g. Alesina et al., 1999), Africa (e.g. Gollwitzer, 2010), OECD countries (e.g. Guichard et al., 2007), EU countries (e.g., De Haan et al., 1999; Ayuso-i-Casals et al., 2007; Debrun et al., 2008; Marneffe et al., 2011; Foremny, 2014) and a panel of industrial and emerging economies (e.g. Singh and Plekhanov, 2006). While Reuter (2014) confirms previous findings for the $\mathrm{EU}$, his results suggest that the effects are not based on a change in fiscal policy after violation of a budget rule but are rather due to increased transparency, monitoring activities and public awareness.

Empirical studies on Switzerland consistently find that cantonal deficit restrictions, i.e., debt brakes, trigger sound public finances within the constrained cantons. In an initial study on cantonal debt brakes, Feld and Kirchgässner (2001a) construct a stringency index that ranges from 0 to 3 for the period 1986-1997. Their results suggest that strong debt brakes have a significantly negative impact on cantonal debt and deficits. Schaltegger (2002) draws a similar conclusion for the years 1980-1998. Feld and Kirchgässner (2008) provide further evidence for the same period that debt brakes significantly reduce cantonal deficits and combined deficits of the cantonal and local level. Krogstrup and Wälti (2008) confirm the previous findings after controlling for voters' preferences. Finally, Yerly (2013) constructs a new fiscal rule index that assigns values between 0 and 100 and finds that harder budget rules reduce cantonal deficits. A somewhat different research question is analyzed by Luechinger and Schaltegger (2013) and Chatagny (2013). Luechinger and Schaltegger (2013) report evidence that debt brakes significantly reduce the probability of projected and realized cantonal deficits. While Chatagny (2013) shows that revenue projection errors are significantly related to the ideology of the cantonal finance minister, debt brakes tend to reduce the ideology impact. In a related strand of literature, Feld et al. (2013) provide evidence that cantonal yield spreads are significantly decreased by strong debt brakes and by the no-bailout regime established subsequent to the Leukerbad Supreme Court decision in 2003. 
However, the overall effect of budget rules on fiscal outcomes might be lower than indicated by the targeted headline variables if the constraints are avoided by means of fiscal gimmickry. In early attempts, Ratchford (1941) and Heins (1963) already addressed this issue. Subsequent analyzes focus either on US states (e.g., Mitchell, 1967; Bennett and DiLorenzo, 1983; von Hagen, 1991, 1992; Bunch, 1991; GAO, 1993; Briffault, 1996; Costello et al., 2012) or EU member countries (e.g., Dafflon and Rossi, 1999; Koen and van den Noord, 2005; von Hagen and Wolff, 2006; Milesi-Ferretti and Moriyama, 2006; Buti et al., 2007; Bernoth and Wolff, 2008; Balduzzi and Grembi, 2011).

While a few studies mention the possibility of vertical effects of fiscal rules (e.g., Heins, 1963; Mitchell, 1967; Briffault, 1996; New, 2001; Sørensen et al., 2001), empirical evidence is scarce. Stansel (1994) provides anecdotal evidence that tax and expenditure limitations in US states lead to a shift of costs to local governments. To the best of our knowledge, so far only four empirical studies touch upon the issue of vertical effects of fiscal rules systematically (Table 1). The first empirical study is conducted by Nice (1991) for the US states. ${ }^{4}$ He constructs the debt limitation variable by calculating the maximum Dollar amount of debt each state can legally issue. He assigns a value of $\$ 9.999$ billion to states without a limitation in 1982 and estimates separate regressions for state debt and combined state and local debt. While the effect of numeric debt limits is positive and significant in both equations, the estimated coefficient is larger (and significant) if only state debt is considered. Similar findings are presented for state balanced budget rules, though statistical significance is not obtained. Von Hagen (1992) analyzes the ratio of US municipal debt in a state and the corresponding state's debt in 1985. His findings suggest that the ratio tends to be larger in states with debt limitations and in states with strong balanced budget rules. Contrary to Nice (1991), von Hagen (1992) concludes that fiscal constraints induce a substitution of local debt for state debt.

Unlike the previous two studies, Kiewiet and Szakaly (1996) employ panel data. To clarify whether different limitations on debt issuance in 49 US states influence local finances over the period 1961-1990 Kiewiet and Szakaly (1996) estimate the effect on state debt and on state and local debt separately. While evidence for the different kinds of limitations is ambiguous,

\footnotetext{
${ }^{4}$ While Abrams and Dougan (1986) do not explicitly address vertical effects of fiscal rules, their analysis already provides some insights regarding this issue. The results suggest that borrowing constraints in US states have a positive impact on state spending and a negative impact on combined spending of the state and local levels albeit both effects are statistically insignificant. However, the authors do not reach any conclusions in that regard.
} 
Kiewiet and Szakaly (1996) conclude that restrictive provisions at the state level lead to more debt issuance at the local level.

Most recently, Feld and Kirchgässner (2008) provide some evidence on vertical effects of cantonal debt brakes in Switzerland employing cantonal deficits and combined cantonal and local deficits as dependent variable. Since the estimated coefficient of the debt brake dummy is highly significant and has almost the same size in both equations, Feld and Kirchgässner (2008: 237) conclude that debt brakes have "no relevant impact on the local deficits". 5

Table $1 \quad$ Summary of studies on vertical effects of fiscal rules

\begin{tabular}{|c|c|c|c|c|c|}
\hline Study & Period & Jurisdictions & $\begin{array}{l}\text { Dependent variable } \\
\text { (selection) }\end{array}$ & Fiscal rule & Vertical effect? \\
\hline Nice (1991) & 1982 & US states & $\begin{array}{l}\text { - State debt } \\
\text { - State and local debt }\end{array}$ & $\begin{array}{l}\text { - Amount of debt } \\
\text { permitted } \\
\text { - Budget rules }\end{array}$ & NO \\
\hline $\begin{array}{l}\text { Von Hagen } \\
\text { (1992) }\end{array}$ & 1985 & US states & $\begin{array}{l}\text { - Debt ratio between } \\
\text { local and state debt }\end{array}$ & $\begin{array}{l}\text { - Debt limitations } \\
\text { - Fiscal rule index (ACIR, } \\
\text { 1987) }\end{array}$ & $\begin{array}{l}\text { YES } \\
\text { (local debt in- } \\
\text { creases) }\end{array}$ \\
\hline $\begin{array}{l}\text { Kiewiet and } \\
\text { Szakaly (1996) }\end{array}$ & $\begin{array}{l}1961- \\
1990\end{array}$ & 49 US states & $\begin{array}{l}\text { - State debt } \\
\text { - State and local debt }\end{array}$ & $\begin{array}{l}\text { - Limitations on bond } \\
\text { issuance }\end{array}$ & $\begin{array}{l}\text { YES } \\
\text { (only for strict } \\
\text { limitations) }\end{array}$ \\
\hline $\begin{array}{l}\text { Feld and Kirch- } \\
\text { gässner (2008) }\end{array}$ & $\begin{array}{l}1980- \\
1998\end{array}$ & $\begin{array}{l}26 \text { Swiss } \\
\text { cantons } \\
\text { ( } 5 \text { with fiscal } \\
\text { rule) }\end{array}$ & $\begin{array}{l}\text { - Cantonal deficit } \\
\text { - Cantonal and local } \\
\text { deficit }\end{array}$ & $\begin{array}{l}\text { - Fiscal rule index (Feld } \\
\text { and Kirchgässner, } \\
\text { 2001a) }\end{array}$ & NO \\
\hline
\end{tabular}

A related strand of literature discusses vertical effects of direct democracy. The findings by Matsusaka (1995) suggest that local spending is higher in US states with popular initiatives. He argues that initiatives shift public spending to local governments due to voters' preferences for local spending. Similarly, Feld et al. (2008) show that centralization of expenditure is less likely in Swiss cantons with direct democracy. While Funk and Gathmann (2011) find only little evidence for an impact of cantonal direct democracy on local spending and decentralization, they provide an alternative explanation for potential vertical effects. Similar to our transmission channels (1), (5) and (6) in Figure 1, Funk and Gathmann (2011) argue that direct democracy on the upper government levels could on the one hand reduce local spending if fewer cantonal resources constrain local revenues (channel 6) or if voters' willingness to devolve

\footnotetext{
${ }^{5}$ While Feld et al. (2010) address the impact of cantonal debt brakes on revenue, they only focus on combined revenue of the cantonal and local level. Thus, the results do not allow for differentiating between an impact on the cantonal and on the municipal level.
} 
responsibilities to the cantonal (instead of local) level is increased (channel 5). ${ }^{6}$ On the other hand, local expenditures could increase if governments try to delegate spending to the local level in order to regain fiscal discretion (channel 1). Another somewhat related field of research focuses on vertical tax externalities. A heap of studies provides evidence in favor of a significant relation between national and sub-national tax rates (see, e.g., Brülhart and Jametti, 2006 and for a survey on the effects of decentralization Baskaran, 2011).

In sum, the few existing studies on vertical effects of fiscal rules put the issue in second place, are inconclusive, use combined data of the regional and local level, or they analyze fairly poor datasets, respectively. Potential effects on fiscal decentralization are not considered by previous research. The only existing paper on vertical effects of fiscal rules in Switzerland (Feld and Kirchgässner, 2008) might fall short of the mark for several reasons: First, the conclusion is derived by examining cantonal deficits and cantonal and local deficits together. This is not sufficient for identification, e.g., if effects of cantonal debt brakes on local expenditure (revenue) are met by equivalent adjustments of local revenue (expenditure), such that local budget deficits do not change. Such a compensation is not unlikely given the large local autonomy on the expenditure and revenue side in combination with broad local fiscal responsibility. Second, the estimation results might be biased since neither municipal controls nor unit fixed effects are employed. Third, the results are based on debt brakes in only five of the 26 cantons. Unlike previous studies, we investigate this question by exploiting a rich panel dataset that covers debt brakes in 17 cantons and various fiscal indicators and other covariates at the municipal level using Difference-in-Differences estimators. In addition, we are, to the best of our knowledge, the first to analyze the effects of fiscal rules on decentralization.

\section{INSTITUTIONAL FRAMEWORK IN SWITZERLAND}

The federal framework of Switzerland is characterized by a strong tradition of fiscal autonomy and responsibility of the federal level, the 26 cantons and the 2,353 municipalities. Despite amalgamations, half of all municipalities still count less than 1,000 residents. While the structure of the local level is subject to cantonal provisions, all cantonal constitutions provide for a division into municipalities. In fact, the local level de facto constitutes the third level of

\footnotetext{
${ }^{6}$ To be precise, Funk and Gathmann (2011) argue that the citizens' willingness to delegate responsibilities to the canton might be increased since direct democratic institutions can help to control overspending.
} 
government and experiences substantial autonomy (Meyer, 2011). ${ }^{7}$ However, the cantons frequently award (remove) mandates to (from) their municipalities in order to coordinate the provision of public services. For instance, in 2004, the fiscal restructuring program of the canton of Zurich mandated the duty to the local level to contribute a basic amount to the funding of inpatient treatment. Since 2012, the canton assumes the full hospital funding, while the funding of home care and nursing home is fully awarded to the municipalities (VZF, 2011). Besides the executive functions related to implementation and administration of cantonal mandates, the municipalities carry out legislative and judicial tasks. The main areas of local responsibility as measured by their spending share are environment and culture and recreation (Table 2).

Table 2 Share of public expenditures in different categories by levels of government, 2010

\begin{tabular}{|c|c|c|c|}
\hline in percentage & Federal level & Cantonal level & Municipal level \\
\hline Administration & 35.9 & 32.2 & 31.9 \\
\hline Security & 36.1 & 46.2 & 17.7 \\
\hline Education & 14.2 & 57.5 & 28.3 \\
\hline Culture and recreation & 8.0 & 31.5 & 60.5 \\
\hline Health care & 3.2 & 83.9 & 12.8 \\
\hline Social welfare & 41.1 & 38.8 & 20.1 \\
\hline Transportation and communication & 44.8 & 32.4 & 22.8 \\
\hline Environment & 14.9 & 22.2 & 63.0 \\
\hline Economy & 43.4 & 41.3 & 15.3 \\
\hline Finances and taxes & 68.4 & 18.9 & 12.6 \\
\hline All areas & 33.6 & 42.3 & 24.1 \\
\hline
\end{tabular}

Note: Social security sector is not shown. Therefore, values in lines may not sum up to $100 \%$. Source: Swiss Federal Department of Finance.

While annual local spending accounts for almost one quarter of total public spending, Switzerland has the lowest share of municipal funding through transfers across the whole of Europe (Council of Europe, 1997: 25). Swiss communities finance on average around 90\% of their spending by own means (Rühli, 2013). They can set surcharges on income taxes relatively autonomously, while tax bases and rates are defined on the cantonal level (Feld et al., 2011). Although local tax burdens vary, complex cantonal schemes of fiscal equalization among communities mitigate the effects of tax competition.

Despite tax and expenditure autonomy, municipalities have the right to borrow and issue debt, however constrained by various budgetary laws. The municipal codes frequently entail provisions for budget balance, initiatives or mandatory and optional referenda, respectively.

\footnotetext{
7 Article 50 as set out in the Swiss Constitution of 1999 states: "The autonomy of the communes shall be guaranteed in accordance with cantonal law. The Confederation shall take account in its activities of the possible consequences for the communes. In doing so, it shall take account of the special position of the cities and urban areas as well as the mountain regions."
} 
Since cantons face - at least a partial - responsibility for local finances all cantons face legal provisions regarding control, supervision, approval and regulation of municipal finances. For instance, all municipalities are required to submit their annual accounts to a cantonal supervisory institution. Local accounting is subject to cantonal authorization in half of all cantons (Finances Publiques, 2004). Still, loopholes and deficiencies in cantonal monitoring became obvious in the case of Leukerbad. In 1999, the municipality of Leukerbad was unable to finance its accumulated CHF 346 million in debt (around CHF 200,000 per capita) and was placed under forced administration and compulsory execution (Beiratschaft) of its canton Valais. Subsequent to a lawsuit by several creditors, the Swiss Supreme Court judged in 2003 that a bailout by the canton of Valais is not justified. The Court nevertheless recommended broadening and intensifying cantonal supervision (Geschäftsprüfungskommission des Grossen Rates, 1999; Swiss Supreme Court 2c.4/2000/mks, 2C.1/2001/mks).

The 26 Swiss cantons enjoy a much larger extent of fiscal autonomy than their municipalities. To secure fiscal sustainability and transparency the Conference of Cantonal Finance Ministers agreed on a role model law for cantonal budgeting in 1981. Among others, the law requires the current budget to be balanced in the medium term and restricts debt increases to investment expenditures. ${ }^{8}$ Until the end of 2012 all cantons but Appenzell Inner-Rhodes, Basel-City and Jura implemented some kind of budget rule in their constitution or budget law (Burret and Feld, 2014). ${ }^{9}$ The 23 cantonal budget rules vary substantially with respect to their design and point of introduction. Feld and Kirchgässner (2001a, 2008) and Feld et al. (2013) exploit this large variation in cantonal fiscal regulations in order to construct a fiscal rule index. They assign an index value between zero and three according to the number of requirements the fiscal rule fulfils. The evaluated components are: (I) a strong link between budget planning and execution, (II) a numeric deficit limit and (III) automatic sanctions. Despite the prevalence of fiscal rules today, we still assign an index value of zero to seven cantons as their constraints do not meet any of the three criteria. Remarkably, all three requirements are only satisfied by the relatively old debt brakes of St. Gall (1929, revised 1997) and Fribourg (1960, revised 1996) and since 2008 by Basel-County. While debt brakes have also been in place for some time in Solothurn

\footnotetext{
${ }^{8}$ For the latest amendment (2013) see Art. 33 and Art. 34 role model law for cantonal budgeting, available from http://www.srs-cspcp.ch/srscspcp.nsf/go/A78FF96571BB620BC1257AFE006B3FDB?OpenDocument\&lng=fr.

${ }^{9}$ Stauffer (2001) and more recently Conference of Cantonal Ministers of Finance (2012) provide a broad overview of cantonal budget rules.
} 
(1986, revised 2005), Grisons (1988) and Appenzell Outer Rhodes (1996), most other cantons followed after the turn of the millennium (Figure 2). ${ }^{10}$ Since the construction of a stringencyindex is always based on subjective judgments, other studies classify some cantons differently across time (e.g., Feld and Kirchgässner, 2008; Feld et al., 2013; Kirchgässner, 2013; Luechinger and Schaltegger, 2013; Yerly 2013).

Figure 2 Stringency index of cantonal fiscal rules, 1980-2013

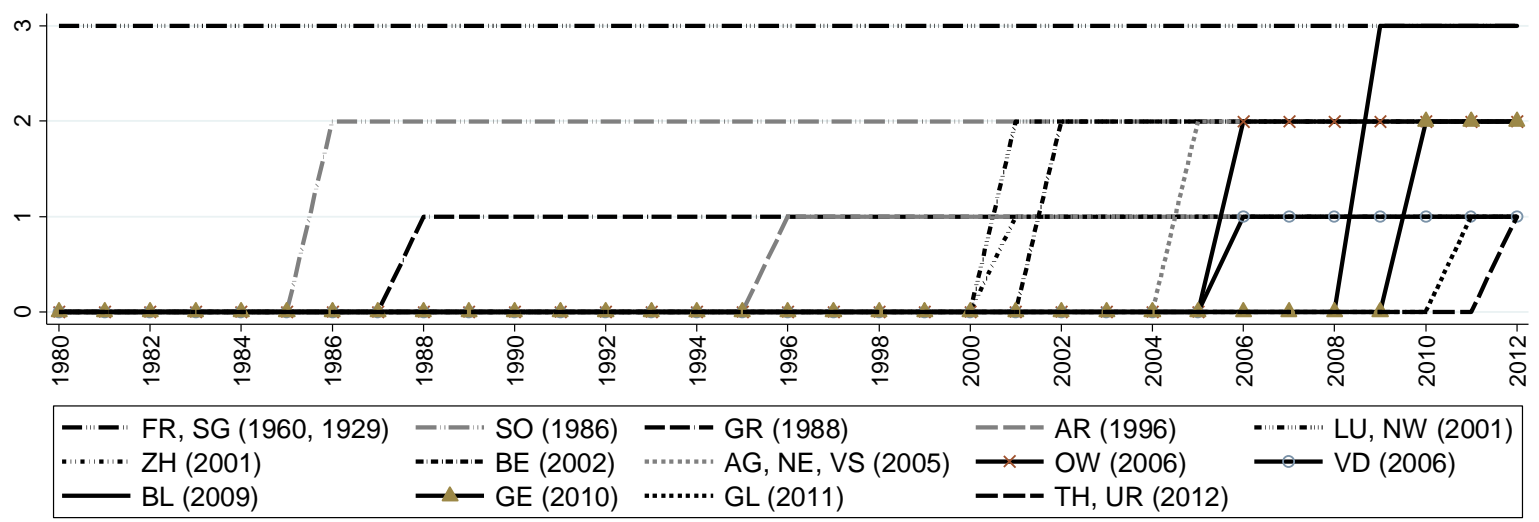

Note: AG Aargau, AR Appenzell Outer-Rhodes, BL Basel-County, BE Bern, FR Fribourg, GE Geneva, GL Glarus, GR Grisons, LU Lucerne, NE Neuchâtel, NI Nidwalden, OW Obwalden, SG St. Gall, SO Solothurn, TH Thurgau, UR Uri, VD Vaud, VS Valais, ZH Zurich. Appenzell Inner-Rhodes (AI), Basel-City (BS), Jura (JU) Schaffhausen (SH), Schwyz (SZ), Ticino (TI) and Zug (ZG) are not depicted since their fiscal rules have not been eligible to classify as debt brakes in any year during the period 1980-2012. Thus, an index value of " 0 " is assigned to them. Illustration based on Feld et al. (2013) and own research.

To conclude, Switzerland provides for an almost ideal institutional setting to examine potential effects of fiscal rules on the finances of lower levels of government. First, despite institutional differences between Swiss cantons, the common political, cultural and constitutional framework implies less heterogeneity across municipalities than across countries such that spurious correlation due to omitted variables is less likely (Luechinger and Schaltegger, 2013). Second, time and canton fixed effects can be employed since debt brakes have been implemented at different points of time. Third, seven cantons have to introduce a (credible) debt brake yet giving us a treatment and a control group. Fourth, cantonal debt brakes do not cover the local level. Fifth, empirical evidence suggests that debt brakes substantially influence cantonal decisions. Sixth, given the cantonal powers to mandate local activities, modify transfers, amend local financial regulations and adjust minimum standards, the cantons have indeed possibilities to avoid their debt brake by influencing local finances. Seventh, Swiss

\footnotetext{
10 The dates in parentheses indicate the year the law became effective.
} 
municipalities are capable to offset potential changes in fiscal burden by autonomous tax adjustments. Against this background, we will test the following two hypotheses:

(1) The introduction of a (strong) debt brake in a canton leads to increased expenditures, revenues, deficits and debts in the municipalities located within that canton.

(2) The introduction of a (strong) debt brake in a canton leads to a higher level of fiscal decentralization in that canton.

\section{Data AND EMpirical Strategy}

In order to test these hypotheses, we use two datasets. The first sample covers harmonized data of the Swiss municipalities aggregated at the cantonal level for each year between 1980 and 2011. We include all cantons except Basel-City, as it is not possible to distinguish between the budget of the canton and its capital. The second sample is comprised of harmonized disaggregated fiscal indicators and covariates of large Swiss cities and communities that have been member of the Swiss Association of Cities during the period of interest (1982-2007). ${ }^{11}$ This second dataset covers around $40 \%$ of the total Swiss population in up to 139 cities with a population size between 2,272 (Arosa) and almost 400,000 (Zurich) inhabitants. Since the sample includes only cantonal capitals and large municipalities, and the cantons of Basel-City and Obwalden are not represented, a selection bias might be present. Thus, the second sample is only supplementary employed.

While a debt brake might induce cantons to adjust municipal mandates, regulatory regimes or transfers, we examine the consequential (indirect) effects on real local expenditure, revenue, debt and deficits. The budget balance variable results from subtracting revenues from expenditures such that a deficit has a positive and a surplus a negative sign. Additionally, real local spending in nine categories, as well as spending and revenue decentralization are separately employed as left-hand side variables. To illustrate the development of the main dependent variables, Figure 3 depicts sample-aggregated data. While local debt per capita peaked in the mid-1990s and subsequently decreased, local spending and revenue increased until the early 1990s and slightly stabilized thereafter. The developments in the left panel of

\footnotetext{
${ }^{11}$ We refrain from including observations after 2007 due to a profound revision in reporting standards. While the Swiss Federal Statistical Office defines municipalities (communities) with a population size above 10,000 as cities, we do not differentiate between the terms.
} 
Figure 3 are partly influenced by a major revision in accounting standards in 2008 with some retroactive effects from 1990. In comparison to the values of almost all communities (left graph), the cantonal capitals and large cities covered by the second sample (right graph) have substantially higher debt, revenue and expenditure per capita and generate budget surpluses less often. This observation supports our concerns of a selection bias in the second sample.

Figure 3 Development of Swiss municipal finances in real Swiss Francs per capita

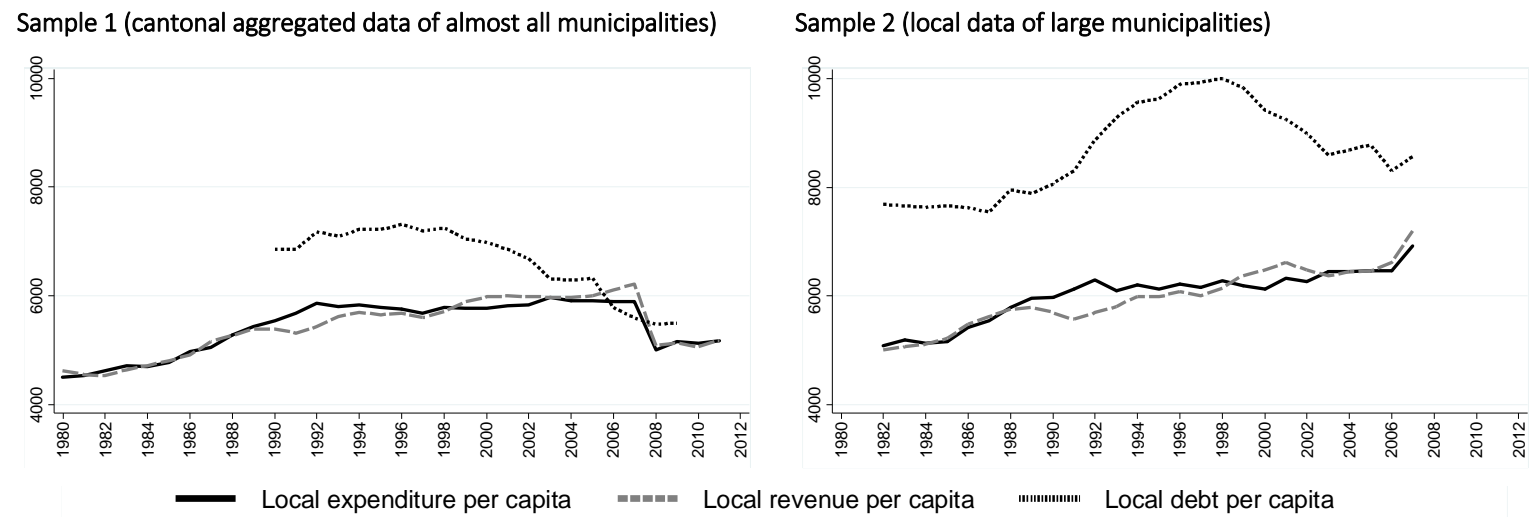

Note: The first sample covers municipalities from all cantons except for Basel-City. The second sample covers between 123 and 139 municipalities from all cantons except for Basel-City and Obwalden. Own illustration based on data from Swiss Federal Finance Administration and Statistical Yearbooks of the Swiss Association of Cities.

Drawing on the literature (e.g., Roubini and Sachs, 1989a, 1989b; De Haan and Sturm, 1994; Shadbegian, 1996; Feld and Kirchgässner, 2001a, 2001b), we employ institutional, economic, socio-demographic and political variables to explain local fiscal outcomes. ${ }^{12}$ Main institutional variables measure the presence and stringency of cantonal fiscal rules, respectively. The local institutional setting, such as the presence of town meetings, municipal parliaments or mandatory fiscal referenda does either not vary sufficiently across time to take it into account, or data is not continuously available. However, indicators of direct democracy at the cantonal level additionally enter the robustness checks. While we could not gather information on budget rules on the local level during the period of interest, evidence suggests that local fiscal constraints do not have a significant impact on local finances (Feld and Kirchgässner, 2001a).

To capture (macro-) economic conditions, we include the unemployment rate ${ }^{13}$, taxable income, indicators of inter-governmental grants (i.e., own revenues) and relative local income. Socio-demographic indicators map the age structure of the population, cultural idiosyncrasies

\footnotetext{
12 Refer to this literature for a broader discussion of our control variables.

${ }^{13} \mathrm{~A}$ direct influence of the level of unemployment on municipal finances is unlikely since unemployment insurance is financed by a federal payroll tax and benefits are regulated by state and cantonal authorities. However, the unemployment rate can be used as a proxy for welfare spending (partly) paid for by the local level of governments.
} 
(approximated by the language) and the number of citizens. Political variables measure the ideology of the government and the number of parties in the municipal executive (only available for the second sample). Table A.1 reports a summary of the descriptive statistics and the mean values and standard deviations separately for municipalities in cantons with and without a debt brake. As indicated by a simple t-test in the last column, the difference of means between the two groups is significant with respect to our main dependent variables in both samples. However, spending and revenue decentralization is not significantly different in the two groups. The definition and the source of each variable are provided in Table A.2. Due to data constraints, each sample's baseline model contains different controls:

Sample/Model 1: Cantonal aggregated local data of almost all municipalities

$$
\begin{aligned}
Y 1_{j, t}=\beta_{0}+ & \beta_{1} \text { Rule }_{c, t}+\beta_{2} \text { Relativelncome }_{j, t}+\beta_{3} \text { Income }_{j, t}+\beta_{4} \text { Unemployment }_{c, t}+ \\
& \beta_{5} \text { Old }_{c, t}+\beta_{6} \text { Young }_{c, t}+\beta_{7} \text { German }_{c, t}+\beta_{8} \text { Pop }_{c, t}+\tau_{t}+\gamma_{c}+\varepsilon_{j, t}
\end{aligned}
$$

Sample/Model 2: Disaggregated local data of 139 large municipalities

$$
\begin{aligned}
Y 2_{i, t}= & \beta_{0}+\beta_{1} \text { Rule }_{c, t}+\beta_{2} \text { Relativelncome }_{i, t}+\beta_{3} \text { Income }_{i, t}+\beta_{4} \text { Unemployment }_{i, t}+ \\
& \beta_{5} \text { Old }_{i, t}+\beta_{6} \text { Young }_{i, t}+\beta_{7} \text { German }_{c, t}+\beta_{8} \text { Pop }_{i, t}+\beta_{9} \text { OWnRev }_{i, t}+\beta_{10} \text { oldeology }_{i, t}+ \\
& \beta_{11} \text { Coalition }_{i, t}+\tau_{t}+\gamma_{c}+\varepsilon_{i, t}
\end{aligned}
$$

where:

Y1

Y2

Per capita real local expenditure, revenue, debt, deficit, spending in nine categories or spending and revenue decentralization (natural log except for deficit and decentralization variables)

Per capita real local expenditure, revenue, debt, deficit, spending in nine categories (natural log except for deficit variable)

Rule

Either a dummy variable that equals one if a cantonal debt brake is in place and zero otherwise or a fiscal rule index that measures the stringency of cantonal debt brakes

Relativelncome Taxable income per capita as share of average taxable income per capita in the sample

Income Real taxable income per capita (natural log)

Unemployment Unemployment rate

OwnRev

Share of own local revenues on total revenues

Young

Share of population younger than 25 years of age

Old

Share of population older than 65 years of age

German

Share of German speaking population

Pop

Population (natural log)

Ideology

Share of left-wing parties in the municipal government

Coalition

Number of political parties in the municipal government 
and $t$ indicates the year, $i$ the municipality, $j$ the municipalities within one canton and $c$ the canton, respectively.

The models are estimated using OLS with canton $(\gamma)$ and time $(\tau)$ fixed effects to control for unobserved heterogeneity and unobserved time-specific factors affecting all entities. ${ }^{14}$ The two-way fixed effects estimator can be seen as a generalization of the Differences-inDifferences estimator as both techniques basically eliminate time trends affecting all units and time-constant differences between the units. ${ }^{15} \mathrm{~A}$ key assumption for such a research design is that the treatment group (municipalities in a canton that is constrained by a debt brake) and control group (municipalities in a canton that is not constrained by a debt brake) would follow a common trend in the absence of treatment. While this is obviously not observable for the treated, similar trends before the treatment can strengthen the validity of the Differences-inDifferences estimates. Figure A.1 illustrates the development of local finances in cantons prior to the introduction of a debt brake (treatment) and in the control groups, respectively. The graphs suggest that local finances followed rather similar trends in all groups. In addition, the common political, cultural and constitutional Swiss framework add to the credibility of the common trend assumption.

The use of two-way fixed effects and the common framework in Switzerland make spurious correlation due to omitted variables less likely. Nevertheless, the effect of cantonal debt brakes might not be the same for all treated units across time. Treatment heterogeneity might particularly be an issue as we examine a long time-period of up to 32 years. For instance, once a debt brake passed it enters into a pre-existing (explicit and implicit) framework that could change over time such that even similarly designed rules may have a different impact if much time passes between their statutory introductions. While vertical effects might particularly be observed during times of fiscal stress at the cantonal level, they might be less pronounced if the economy is running smoothly. In addition, the common trend assumption is hard to defend for long periods by the consideration of pre-treatment trends. Thus, the robustness analysis separately examines the effect of "early" and "late" debt brake adopters and studies the influence of fiscal stress at the cantonal level. Alongside, the investigation of sub-periods helps

\footnotetext{
14 The robustness analysis provides the results of models without fixed effects.

15 Simplified, the Differences-in-Differences estimator can be written as:

$\widehat{\beta}=\left(\bar{y}^{\text {treatment units after treatment }}-\bar{y}^{\text {treatment units before treatment }}\right)-\left(\bar{y}^{\text {control units after treatment }}-\bar{y}^{\text {control units before treatment }}\right)$.
} 
to cope with structural brakes due to a major revision in accounting standards in 2008 with retroactive effect back to 1990 .

On the one hand, endogeneity of the cantonal debt brakes is less of an issue since the municipalities enjoy large autonomy and the institutional variable varies only slightly over time. On the other hand, the rules reflect voters' preference since they are commonly subject to referenda. Thus, it is questionable whether the estimated effect is causal on the debt brake or on voters' preferences. To clarify whether debt brakes induce structural breaks, we calculate standard Chow breakpoint tests. The test has the null hypothesis that parameters (slopes and the intercept) of municipalities located in cantons with a debt brake are not different from those of the other group. ${ }^{16}$ If the null hypothesis is rejected, cantonal debt brakes induce a break in the regression coefficients. In addition, we follow Poterba $(1996,1997)$ and address potential endogeneity of fiscal institutions by controlling for voters' preferences. We adapt a frequent approach and use the share of left-wing parties in the municipal executive as an indicator of voters' preferences in the second sample. In the robustness analysis we further investigate the issue by using the information on voters' fiscal preferences revealed through the nationwide referendum on the federal debt brake in 2001 to divide the first sample into two sub-panels: One panel with fiscally conservative voters (municipalities with approval rates above the average) and a panel with voters that revealed low preferences for fiscal consolidation (municipalities with approval rates below the average). If the estimated effect in the two sub-panels is similar, the impact seems rather independent from voters' preferences. While the referendum captures only one point in time, Dafflon and Pujol (2001) suggest that voters' fiscal preferences are largely time-invariant. In such a case voters' preferences are, at least partly, captured by the fixed effects. Endogeneity of our economic controls is less of an issue as they are unlikely to be influenced by the dependent variables within the same year.

Panel data frequently result in biased standard errors due to autocorrelation of the error terms. Cross-sectional dependence in errors arises from common shocks and unobserved components, respectively. In fact, the Pesaran (2004) pre-estimation test rejects error crosssection independence for all outcome variables of the first sample at the $1 \%$ level except for

\footnotetext{
${ }^{16}$ To be precise, for Chow breakpoint tests we run two-way fixed effects regressions between the outcome variable and all explanatory variables along with interaction terms between the debt brake dummy and each control variable (except for fixed effects) and include a constant. Subsequently, we run F-tests on the debt brake dummy and the coefficients for the interaction terms.
} 
administrative spending (Table A.5). ${ }^{17}$ A common solution are cluster-robust standard errors. However, a small number of clusters can lead to a substantial downward bias of estimated standard errors and, thus, an overstatement of statistical significance (Cameron et al., 2008; Angrist and Pischke, 2009). For accurate inference, the data should have at least 50 clusters of roughly equal sizes or at least 20 balanced clusters (Kézdi, 2004; Nichols and Schaffer, 2007). Rogers (1993) suggests that a cluster should not contain more than five percent of the sample data. As the first (aggregated) dataset comprises 25 cantons and data are almost equally distributed among cantons, we adjust the errors for clustering on the cantonal level and correct for heteroscedasticity following Luechinger and Schaltegger (2013) who examine a similar dataset and conclude that clustering at the cantonal level does rather not imply a substantial bias with reference to simulations by Bertrand et al. (2004) and Cameron et al. (2008).

Our second sample is different though. The 139 municipalities are considerably differently distributed among the 24 cantons that the second sample covers. For instance, 24 communities are located in Zurich and 18 in Berne, while the dataset covers only one municipality from Uri, Nidwalden, Glarus and both Appenzells, respectively. Since the cantonal cluster sizes would be largely unbalanced in this case, the cure of cluster-robust standard errors could be worse than the disease (Nichols and Schaffer, 2007). Thus, cluster-robust standard errors are only reported for the first sample. To further improve inference in both datasets we calculate robust standard errors based on the wild-cluster bootstrap-t procedure. The resampling method relaxes the restriction of equally sized clusters and has been found to work well in cases with few clusters (Cameron et al., 2008; Cameron and Miller, 2013). ${ }^{18}$ In addition, it is quite robust to differences in the number of units in the treatment and control groups (Mackinnon and Webb, 2014). Thus, statistical inference is based on cluster-robust standard errors and bootstrapped p-values in the first sample and solely on bootstrapped p-values in the second sample.

\footnotetext{
${ }^{17}$ The highly unbalanced second sample provides too few common observations across the panel to perform the test.

18 The method uses the wild bootstrap to resample clusters of residuals obtained from regressions which impose the null hypothesis $(B=0)$ and re-estimates the original equation with the newly generated residuals. The pseudo samples of clusters is formed by multiplying the residuals with 1 and -1 with a probability of 0.5 . The so-called Rademacher weight provides asymptotic refinement. See Cameron et al. (2008) for details. We employ the Stata post-estimation command "bootwildct" provided by Malde (2012) with 1000 repetitions.
} 


\section{BASELINE RESULTS ${ }^{19}$}

\subsection{Vertical Effects on Expenditure, Revenue, Debt and Deficit}

Table 3 presents the baseline regressions for the first model of cantonal aggregated local expenditure, revenue, deficits and debt. Following the Wald test results, we include canton and year fixed effects. While the estimated baseline model explains around $60 \%$ of the variance of the expenditure and revenue equations, it has notably less explanatory power regarding debt and deficits. Contrary to hypothesis (1), the results suggest that the introduction of a cantonal debt brake induces local expenditure, revenue, deficits, and debt to decrease. According to these estimates, the presence of a cantonal fiscal rule reduces per capita local spending by almost $3 \%$, local revenue by around $2.2 \%$ and local debt by around $1 \%$. However, neither the debt brake dummy nor the fiscal rule index are statistically significant in any equation (confirmed by the bootstrapped p-values, Table 3 in brackets). Regarding controls, population, unemployment and language differences turn out to be significant in at least some equations.

Table 3 Baseline regression of sample 1: Local finances aggregated at the cantonal level, 1980-2011

\begin{tabular}{|c|c|c|c|c|c|c|c|c|}
\hline & \multicolumn{2}{|c|}{ Expenditure } & \multicolumn{2}{|c|}{ Revenue } & \multicolumn{2}{|c|}{ Debt } & \multicolumn{2}{|c|}{ Deficit } \\
\hline Debt brake & $\begin{array}{r}-0.029 \\
(-1.008) \\
{[0.358]}\end{array}$ & & $\begin{array}{r}-0.022 \\
(-0.852) \\
{[0.410]}\end{array}$ & & $\begin{array}{r}-0.008 \\
(-0.202) \\
{[0.843]}\end{array}$ & & $\begin{array}{r}-48.654 \\
(-0.990) \\
{[0.346]}\end{array}$ & \\
\hline Fiscal rule index & & $\begin{array}{r}-0.013 \\
(-0.725) \\
{[0.555]}\end{array}$ & & $\begin{array}{r}-0.007 \\
(-0.433) \\
{[0.687]}\end{array}$ & & $\begin{array}{r}-0.008 \\
(-0.347) \\
{[0.747]}\end{array}$ & & $\begin{array}{r}-34.561 \\
(-1.297) \\
{[0.254]}\end{array}$ \\
\hline Unemployment & $\begin{array}{r}-0.373 \\
(-0.346)\end{array}$ & $\begin{array}{r}-0.378 \\
(-0.351)\end{array}$ & $\begin{array}{r}-0.438 \\
(-0.430)\end{array}$ & $\begin{array}{r}-0.428 \\
(-0.420)\end{array}$ & $\begin{array}{l}-3.216^{*} \\
(-1.817)\end{array}$ & $\begin{array}{l}-3.215^{*} \\
(-1.826)\end{array}$ & $\begin{array}{r}-375.481 \\
(-0.209)\end{array}$ & $\begin{array}{r}-464.573 \\
(-0.255)\end{array}$ \\
\hline Relative income & $\begin{array}{r}-9.266 \\
(-0.631)\end{array}$ & $\begin{array}{r}-9.046 \\
(-0.602)\end{array}$ & $\begin{array}{l}-19.596 \\
(-1.364)\end{array}$ & $\begin{array}{l}-18.939 \\
(-1.314)\end{array}$ & $\begin{array}{l}-18.111 \\
(-0.523)\end{array}$ & $\begin{array}{l}-19.434 \\
(-0.579)\end{array}$ & $\begin{array}{r}2,3587.218 \\
(0.925)\end{array}$ & $\begin{array}{r}2,1284.505 \\
(0.805)\end{array}$ \\
\hline Income & $\begin{array}{r}0.427 \\
(0.611)\end{array}$ & $\begin{array}{r}0.422 \\
(0.593)\end{array}$ & $\begin{array}{r}0.961 \\
(1.320)\end{array}$ & $\begin{array}{r}0.936 \\
(1.287)\end{array}$ & $\begin{array}{r}0.375 \\
(0.218)\end{array}$ & $\begin{array}{r}0.433 \\
(0.258)\end{array}$ & $\begin{array}{r}-1,335.729 \\
(-1.155)\end{array}$ & $\begin{array}{r}-1,229.828 \\
(-1.026)\end{array}$ \\
\hline Population & $\begin{array}{r}0.403 * * \\
(2.511)\end{array}$ & $\begin{array}{r}0.403^{* *} \\
(2.463)\end{array}$ & $\begin{array}{l}0.311^{*} \\
(1.806)\end{array}$ & $\begin{array}{c}0.310 * \\
(1.775)\end{array}$ & $\begin{array}{r}-1.728^{* * *} \\
(-3.497)\end{array}$ & $\begin{array}{r}-1.725^{* * *} \\
(-3.500)\end{array}$ & $\begin{array}{r}296.935 \\
(0.770)\end{array}$ & $\begin{array}{r}303.010 \\
(0.785)\end{array}$ \\
\hline Share old & $\begin{array}{r}1.104 \\
(1.502)\end{array}$ & $\begin{array}{r}1.211 \\
(1.528)\end{array}$ & $\begin{array}{r}0.680 \\
(0.809)\end{array}$ & $\begin{array}{r}0.746 \\
(0.828)\end{array}$ & $\begin{array}{r}-1.815 \\
(-0.641)\end{array}$ & $\begin{array}{r}-1.721 \\
(-0.609)\end{array}$ & $\begin{array}{r}1,429.810 \\
(0.893)\end{array}$ & $\begin{array}{r}1,703.651 \\
(1.097)\end{array}$ \\
\hline Share young & $\begin{array}{r}0.529 \\
(0.734)\end{array}$ & $\begin{array}{r}0.516 \\
(0.714)\end{array}$ & $\begin{array}{r}0.463 \\
(0.616)\end{array}$ & $\begin{array}{r}0.446 \\
(0.591)\end{array}$ & $\begin{array}{r}2.692 \\
(1.604)\end{array}$ & $\begin{array}{r}2.711 \\
(1.618)\end{array}$ & $\begin{array}{r}527.184 \\
(0.377)\end{array}$ & $\begin{array}{r}538.765 \\
(0.384)\end{array}$ \\
\hline Share German & $\begin{array}{r}-0.058 \\
(-0.111)\end{array}$ & $\begin{array}{r}-0.089 \\
(-0.177)\end{array}$ & $\begin{array}{r}-0.437 \\
(-0.880)\end{array}$ & $\begin{array}{r}-0.462 \\
(-0.970)\end{array}$ & $\begin{array}{r}0.761 \\
(0.596)\end{array}$ & $\begin{array}{r}0.746 \\
(0.586)\end{array}$ & $\begin{array}{r}1,435.144^{* *} \\
(2.354)\end{array}$ & $\begin{array}{r}1,380.639 * * \\
(2.221)\end{array}$ \\
\hline Adj. R2 & 0.58 & 0.58 & 0.60 & 0.60 & 0.44 & 0.44 & 0.23 & 0.23 \\
\hline $\begin{array}{l}\mathrm{N} \\
\text { Cluster }\end{array}$ & $\begin{array}{r}800 \\
25\end{array}$ & $\begin{array}{r}800 \\
25\end{array}$ & $\begin{array}{r}800 \\
25\end{array}$ & $\begin{array}{r}800 \\
25\end{array}$ & $\begin{array}{r}550 \\
25\end{array}$ & $\begin{array}{r}550 \\
25\end{array}$ & $\begin{array}{r}800 \\
25\end{array}$ & $\begin{array}{r}800 \\
25\end{array}$ \\
\hline $\begin{array}{l}\text { Wald test: FE } \\
\text { Chow test }\end{array}$ & $\begin{array}{r}897.21^{* * *} \\
4.82^{* * *} \\
\end{array}$ & $597.98 * * *$ & $\begin{array}{r}639.96 * * * \\
1.99 * \\
\end{array}$ & $588.47 * * *$ & $\begin{array}{r}2,289.92 * * * \\
3.40 * * *\end{array}$ & $7,374.84 * * *$ & $\begin{array}{r}69.80 * * * \\
6.48 * * *\end{array}$ & $135.58^{* * *}$ \\
\hline
\end{tabular}

Note: Due to data limitations, public debt is analyzed during the years 1990-2009. Canton and year fixed effects included. Constant not shown. The numbers in parentheses indicate the estimated t-statistics for standard errors adjusted for clustering at the cantonal level and corrected for heteroscedasticity. These values are used to determine statistical significance: ${ }^{*} p<0.1$ (significance at the $10 \%$ level), ${ }^{* *} p<0.05$ (significance at the $5 \%$ level), and $* * * p<0.01$ (significance at the $1 \%$ level). The numbers in brackets indicate the estimated $p$-values for the fiscal rule variables using the wild-cluster bootstrap-t procedure. The Wald test has the null hypothesis that the fixed effects are jointly equal to zero. The Chow test has the null hypothesis that the parameters of municipalities located in cantons with a debt brake are equal to those of the other group. For Wald and Chow tests, we report test statistics based on regressions with cluster-robust standard errors.

\footnotetext{
${ }^{19}$ All estimates are performed with Stata 13 . The discussion is primarily restricted to the main variables of interest.
} 


\begin{tabular}{|c|c|c|c|c|c|c|c|c|}
\hline & Expenditure & & Revenue & & Debt & & Deficit & \\
\hline Debt brake & $\begin{array}{r}-0.030 \\
\{-2.090\} \\
{[0.713]}\end{array}$ & & $\begin{array}{r}-0.049 \\
\{-3.516\} \\
{[0.442]}\end{array}$ & & $\begin{array}{r}-0.008 \\
\{-0.222\} \\
{[0.959]}\end{array}$ & & $\begin{array}{l}82.010 \\
\{1.991\} \\
{[0.386]}\end{array}$ & \\
\hline Fiscal rule index & & $\begin{array}{r}-0.033 \\
\{-3.694\} \\
{[0.677]}\end{array}$ & & $\begin{array}{r}-0.040 \\
\{-4.686\} \\
{[0.536]}\end{array}$ & & $\begin{array}{r}-0.002 \\
\{-0.089\} \\
{[0.983]}\end{array}$ & & $\begin{array}{l}24.710 \\
\{0.978\} \\
{[0.466]}\end{array}$ \\
\hline Unemployment & $\begin{array}{r}-0.060 \\
{[0.957]}\end{array}$ & $\begin{array}{r}-0.135 \\
{[0.871]}\end{array}$ & $\begin{array}{c}-0.315 \\
{[0.719]}\end{array}$ & $\begin{array}{r}-0.390 \\
{[0.565]}\end{array}$ & $\begin{array}{r}1.884 \\
{[0.438]}\end{array}$ & $\begin{array}{r}1.887 \\
{[0.422]}\end{array}$ & $\begin{array}{r}1^{\prime} 036.639 \\
{[0.565]}\end{array}$ & $\begin{array}{r}1^{\prime} 012.187 \\
{[0.597]}\end{array}$ \\
\hline Relative income & $\begin{array}{r}0.150 \\
{[0.655]}\end{array}$ & $\begin{array}{r}0.146 \\
{[0.645]}\end{array}$ & $\begin{array}{r}0.122 \\
{[0.705]}\end{array}$ & $\begin{array}{r}0.119 \\
{[0.665]}\end{array}$ & $\begin{array}{r}0.432 \\
{[0.308]}\end{array}$ & $\begin{array}{r}0.433 \\
{[0.290]}\end{array}$ & $\begin{array}{l}86.082 \\
{[0.609]}\end{array}$ & $\begin{array}{r}79.753 \\
{[0.665]}\end{array}$ \\
\hline Income & $\begin{array}{r}0.161 \\
{[0.639]}\end{array}$ & $\begin{array}{r}0.166 \\
{[0.579]}\end{array}$ & $\begin{array}{r}0.224 \\
{[0.514]}\end{array}$ & $\begin{array}{r}0.227 \\
{[0.496]}\end{array}$ & $\begin{array}{r}-0.544 \\
{[0.216]}\end{array}$ & $\begin{array}{r}-0.545 \\
{[0.240]}\end{array}$ & $\begin{array}{r}-257.972 \\
{[0.394]}\end{array}$ & $\begin{array}{r}-249.239 \\
{[0.398]}\end{array}$ \\
\hline Population & $\begin{array}{l}0.087^{*} \\
{[0.074]}\end{array}$ & $\begin{array}{l}0.086^{*} \\
{[0.054]}\end{array}$ & $\begin{array}{r}0.079 \\
{[0.114]}\end{array}$ & $\begin{array}{r}0.078 \\
{[0.128]}\end{array}$ & $\begin{array}{l}0.214^{*} \\
{[0.078]}\end{array}$ & $\begin{array}{l}0.214^{*} \\
{[0.078]}\end{array}$ & $\begin{array}{r}53.535^{* *} \\
{[0.014]}\end{array}$ & $\begin{array}{r}53.167^{* *} \\
{[0.012]}\end{array}$ \\
\hline Share own revenue & $\begin{array}{r}-1.126^{* * *} \\
{[0.006]}\end{array}$ & $\begin{array}{r}-1.139 * * * \\
{[0.004]}\end{array}$ & $\begin{array}{r}-1.061 * * * \\
{[0.002]}\end{array}$ & $\begin{array}{r}-1.070 * * \\
{[0.010]}\end{array}$ & $\begin{array}{r}-1.404 * * * \\
{[0.004]}\end{array}$ & $\begin{array}{r}-1.401 * * * \\
{[0.004]}\end{array}$ & $\begin{array}{r}-464.224 * \\
{[0.084]}\end{array}$ & $\begin{array}{r}-486.143 \\
{[0.102]}\end{array}$ \\
\hline Share young & $\begin{array}{r}-2.882 * * \\
{[0.036]}\end{array}$ & $\begin{array}{r}-2.897 * * \\
{[0.026]}\end{array}$ & $\begin{array}{r}-2.814^{* *} \\
{[0.036]}\end{array}$ & $\begin{array}{r}-2.827^{* *} \\
{[0.016]}\end{array}$ & $\begin{array}{r}-2.644 \\
{[0.310]}\end{array}$ & $\begin{array}{r}-2.642 \\
{[0.356]}\end{array}$ & $\begin{array}{r}-65.346 \\
{[0.817]}\end{array}$ & $\begin{array}{r}-81.601 \\
{[0.821]}\end{array}$ \\
\hline Share old & $\begin{array}{l}1.138^{*} \\
{[0.094]}\end{array}$ & $\begin{array}{r}1.134 \\
{[0.116]}\end{array}$ & $\begin{array}{r}1.000 \\
{[0.128]}\end{array}$ & $\begin{array}{r}0.995 \\
{[0.130]}\end{array}$ & $\begin{array}{r}0.943 \\
{[0.587]}\end{array}$ & $\begin{array}{r}0.942 \\
{[0.595]}\end{array}$ & $\begin{array}{r}712.226 \\
{[0.240]}\end{array}$ & $\begin{array}{r}718.954 \\
{[0.218]}\end{array}$ \\
\hline Share German & $\begin{array}{r}-0.391 \\
{[0.528]}\end{array}$ & $\begin{array}{l}-0.407 \\
{[0.520]}\end{array}$ & $\begin{array}{r}-0.600 \\
{[0.132]}\end{array}$ & $\begin{array}{r}-0.599 \\
{[0.110]}\end{array}$ & $\begin{array}{r}0.849 \\
{[0.484]}\end{array}$ & $\begin{array}{r}0.859 \\
{[0.458]}\end{array}$ & $\begin{array}{r}188.125 \\
{[0.919]}\end{array}$ & $\begin{array}{l}94.058 \\
{[0.978]}\end{array}$ \\
\hline Ideology gov't & $\begin{array}{r}-0.104 \\
{[0.290]}\end{array}$ & $\begin{array}{l}-0.103 \\
{[0.314]}\end{array}$ & $\begin{array}{r}-0.055 \\
{[0.635]}\end{array}$ & $\begin{array}{l}-0.054 \\
{[0.615]}\end{array}$ & $\begin{array}{r}0.091 \\
{[0.691]}\end{array}$ & $\begin{array}{r}0.091 \\
{[0.663]}\end{array}$ & $\begin{array}{r}-284.768 * * * \\
{[0.002]}\end{array}$ & $\begin{array}{r}-283.189 * * * \\
{[0.006]}\end{array}$ \\
\hline Coalition gov't & $\begin{array}{r}-0.020 \\
{[0.274]}\end{array}$ & $\begin{array}{r}-0.020 \\
{[0.342]}\end{array}$ & $\begin{array}{c}-0.022 \\
{[0.282]}\end{array}$ & $\begin{array}{r}-0.021 \\
{[0.316]}\end{array}$ & $\begin{array}{r}-0.035 \\
{[0.382]}\end{array}$ & $\begin{array}{l}-0.035 \\
{[0.420]}\end{array}$ & $\begin{array}{r}7.255 \\
{[0.617]}\end{array}$ & $\begin{array}{r}6.010 \\
{[0.660]}\end{array}$ \\
\hline $\begin{array}{l}\text { Adj. R2 } \\
N\end{array}$ & $\begin{array}{r}0.45 \\
3,329\end{array}$ & $\begin{array}{l}0.445 \\
3,329\end{array}$ & $\begin{array}{r}0.46 \\
3,329\end{array}$ & $\begin{array}{r}0.46 \\
3,329\end{array}$ & $\begin{array}{r}0.17 \\
3,329\end{array}$ & $\begin{array}{r}0.17 \\
3,329\end{array}$ & $\begin{array}{r}0.07 \\
3,329\end{array}$ & $\begin{array}{r}0.07 \\
3,329\end{array}$ \\
\hline $\begin{array}{l}\text { Wald test: FE } \\
\text { Chow test }\end{array}$ & $\begin{array}{l}62.65^{* * *} \\
15.53^{* * *}\end{array}$ & $64.44 * * *$ & $\begin{array}{l}67.35^{* * *} \\
18.08^{* * *}\end{array}$ & $69.60 * * *$ & $\begin{array}{l}22.54^{* * *} \\
12.50^{* * *}\end{array}$ & $22.61 * * *$ & $\begin{array}{l}6.35^{* * *} \\
3.80^{* * *}\end{array}$ & $6.34 * * *$ \\
\hline
\end{tabular}

Note: Canton and year fixed effects are included. Constant not shown. The numbers in brackets indicate the estimated p-values using the wildcluster bootstrap-t procedure. These values are used to determine statistical significance: ${ }^{*} p<0.1$ (significance at the $10 \%$ level), ${ }^{* *} p<0.05$ (significance at the $5 \%$ level), and $* * * p<0.01$ (significance at the $1 \%$ level). Number in braces indicate estimated t-statistics for default standard errors. The Wald test has the null hypothesis that the fixed effects are jointly equal to zero. The Chow test has the null hypothesis that the parameters of municipalities located in cantons with a debt brake are equal to those of the other group. For Wald and Chow tests we report test statistics based on regressions default standard errors.

While the second sample covers large cities only and additionally includes political controls and an indicator of local grants, the previous sample's findings are largely confirmed (Table 4). Like in sample one, we follow Wald test results and apply cantonal and year fixed effects. As suggested by the first sample, cantonal debt brakes reduce local spending, revenue and debt. Conversely, they have a positive impact on local deficits. The statistical significance of the estimated effects depends on the standard errors under consideration. The default standard errors (corresponding t-statistics in braces) indicate a statistically significant impact of debt brakes in most cases. However, the default standard errors may suffer from autocorrelation and heteroscedasticity. As discussed in Section 4, it seems thus appropriate to base statistical inference in the second sample on $p$-values computed by the wild-cluster bootstrap-t procedure. In compliance with the first sample's findings, the bootstrapped p-values reveal that the debt brake or the fiscal rule index do not reach statistical significance in any equation. 
While the local unemployment rate, income and relative income are not statistically significant, Wald tests suggest that the variables jointly matter for fiscal outcomes. ${ }^{20}$ Like in the first sample, statistical significance obtains with respect to socio-demographic variables. In addition, own revenues are (highly) significant in all equations. As commonly assumed, a larger share of own local revenues on total local revenues reduces municipal spending, revenue, deficits and debt. Political controls provide some noteworthy insights: While previous evidence suggests that expenditure and debt increase if more parties are involved in the executive (e.g., Feld et al., 2010; Volkerink and de Haan, 2001), our coalition variable indicates a contrary effect though p-values are far from indicating significance. The ideology variable that measures the share of left-wing parties in the municipal executive is significant at the $1 \%$ level in the deficit equation but does not have the expected sign.

\subsection{Vertical EfFects on Different Spending CATEgories}

Recent evidence for US states suggests that budget rules have a stronger impact on states' finances and fiscal sustainability the more narrowly defined the underlying budget balance variable is (e.g., Hou and Smith, 2010; Mahdavi and Westerlund, 2011). While different indicators of local budget balances are not available, we investigate whether the effect of fiscal rules is more pronounced if more narrowly defined expenditure categories are considered instead of total spending. Municipalities might react to a cantonally induced spending rise in a certain area by reallocating their spending among different categories with the result that total spending is largely unaffected. To investigate this possibility we examine nine spending categories during the years 1990-2011 (sample 1) and 1982-2007 (sample 2), respectively.

Similar to the previous estimations, the results suggest that budget rules reduce local spending at least in some categories (Table A.3 and A.4). However, in most spending areas the estimated signs of the debt brake coefficients contradict each other in the two datasets. This might be due to deviations in the definition of each spending area between the two samples. A similar effect in both samples obtains with respect to spending on education (negative) and other areas (positive). Moreover, the coefficients are not statistically significant in most cases. In fact, a statistically meaningful impact of both debt brake variables only results for transportation spending in the first sample. Here the cluster-robust standard errors and bootstrapped p-values

\footnotetext{
${ }^{20}$ Wald tests are based on regressions with default standard errors.
} 
both suggest a significantly negative effect. The finding seems plausible since local autonomy tends to be rather small (except for larger cities) regarding transportation issues, with the result that cantons may enforce an adjustment in local spending in this area relatively easily. In sum, we find hardly any conclusive evidence that cantonal debt brakes influence local expenditure neither in its entirety nor in certain spending areas.

\subsection{Vertical Effects on Fiscal Decentralization}

While related studies reveal that cantonal debt brakes support fiscal discipline at the cantonal level (e.g., Feld and Kirchgässner, 2001a, 2008; Schaltegger, 2002; Krogstrup and Wälti, 2008; Luechinger and Schaltegger, 2013), our baseline findings suggest that cantonal debt brakes do not significantly affect finances at the local level. This raises the related question, whether cantonal budget rules affect fiscal decentralization. Given the large autonomy of Swiss municipalities on the expenditure and revenue side, we employ two measures of fiscal decentralization to investigate this question: Spending (revenue) decentralization is measured by the ratio of local spending (revenue) in a canton to local and cantonal spending (revenue) in that canton, i.e. $\left(\frac{\text { Local }}{\text { Cantonal }+ \text { Local }}\right)$.

Table 5 presents similar findings for both decentralization indicators. ${ }^{21}$ Contrary to hypothesis (2), the results suggest that cantonal debt brakes reduce fiscal decentralization, i.e., lead to a higher level of cantonal as compared to local spending or revenue, respectively. While the fiscal rule index turns out to be insignificant, the debt brake dummy reaches statistical significance at the $10 \%$ level in the expenditure decentralization equation (1) and at the $5 \%$ level if revenue decentralization (3) is considered. The more conservative $p$-values based on the wild-cluster bootstrap-t procedure confirm statistical significance, though only at the $10 \%$ level. Thus, we find little evidence for an impact of cantonal debt brakes on fiscal decentralization.

This matches quite well with the above findings (i.e., the numerator - be it expenditures or revenues - is not significantly affected by cantonal fiscal rules) and previous evidence that

\footnotetext{
${ }^{21}$ Since the second sample covers only one municipality from some cantons (e.g., Uri, Nidwalden, Glarus) it does not seem to be reasonable to employ a decentralization variable which is calculated for all municipalities within a canton as dependent variable. For similar reasons we refrain from calculating a decentralization variable by using total cantonal expenditure and spending data of the few municipalities recorded within a canton by the second sample. Thus, the analysis is only conducted with data from the first sample, i.e., data covering all municipalities within a canton.
} 
cantonal debt brakes hardly affect cantonal revenue and expenditure, respectively (Feld et al., 2010; Schaltegger, 2002; Feld and Kirchgässner, 2001a). Among our controls, only income and relative income turn out to be statistically significant.

Table 5 Baseline regression of sample 1: Effect of fiscal rules on decentralization, 1980-2011

\begin{tabular}{|c|c|c|c|c|}
\hline & \multicolumn{2}{|c|}{ Spending decentralization } & \multicolumn{2}{|c|}{ Revenue decentralization } \\
\hline & $(1)$ & $(2)$ & (3) & $(4)$ \\
\hline Debt brake & $\begin{array}{c}-0.017^{*} \\
(-1.909) \\
{[0.088]}\end{array}$ & & $\begin{array}{r}-0.021^{* *} \\
(-2.275) \\
{[0.064]}\end{array}$ & \\
\hline Fiscal rule index & & $\begin{array}{r}-0.009 \\
(-1.623) \\
{[0.154]}\end{array}$ & & $\begin{array}{r}-0.009 \\
(-1.543) \\
{[0.178]}\end{array}$ \\
\hline Unemployment & $\begin{array}{r}-0.052 \\
(-0.122)\end{array}$ & $\begin{array}{r}-0.060 \\
(-0.142)\end{array}$ & $\begin{array}{r}0.148 \\
(0.331)\end{array}$ & $\begin{array}{r}0.145 \\
(0.319)\end{array}$ \\
\hline Relative income & $\begin{array}{r}-0.452 * * \\
(-2.121)\end{array}$ & $\begin{array}{r}-0.454^{* *} \\
(-2.064)\end{array}$ & $\begin{array}{r}-13.886^{* *} \\
(-2.437)\end{array}$ & $\begin{array}{r}-13.713^{* *} \\
(-2.307)\end{array}$ \\
\hline Income & $\begin{array}{c}0.452^{*} \\
(1.865)\end{array}$ & $\begin{array}{c}0.457^{*} \\
(1.824)\end{array}$ & $\begin{array}{r}0.579 * * \\
(2.243)\end{array}$ & $\begin{array}{r}0.575^{* *} \\
(2.136)\end{array}$ \\
\hline Population & $\begin{array}{r}0.148 \\
(1.615)\end{array}$ & $\begin{array}{r}0.148 \\
(1.619)\end{array}$ & $\begin{array}{r}0.136 \\
(1.440)\end{array}$ & $\begin{array}{r}0.136 \\
(1.439)\end{array}$ \\
\hline Share old & $\begin{array}{r}0.288 \\
(0.989)\end{array}$ & $\begin{array}{r}0.359 \\
(1.158)\end{array}$ & $\begin{array}{r}0.342 \\
(1.105)\end{array}$ & $\begin{array}{r}0.420 \\
(1.216)\end{array}$ \\
\hline Share young & $\begin{array}{r}0.052 \\
(0.194)\end{array}$ & $\begin{array}{r}0.046 \\
(0.172)\end{array}$ & $\begin{array}{r}-0.080 \\
(-0.297)\end{array}$ & $\begin{array}{r}-0.091 \\
(-0.331)\end{array}$ \\
\hline Share German & $\begin{array}{r}0.130 \\
(1.097)\end{array}$ & $\begin{array}{r}0.111 \\
(0.877)\end{array}$ & $\begin{array}{r}0.072 \\
(0.595)\end{array}$ & $\begin{array}{r}0.049 \\
(0.369)\end{array}$ \\
\hline Adj. R2 & 0.58 & 0.58 & 0.57 & 0.56 \\
\hline $\begin{array}{l}\mathrm{N} \\
\text { Cluster }\end{array}$ & $\begin{array}{r}800 \\
25\end{array}$ & $\begin{array}{r}800 \\
25\end{array}$ & $\begin{array}{r}800 \\
25\end{array}$ & $\begin{array}{r}800 \\
25\end{array}$ \\
\hline $\begin{array}{l}\text { Wald test: FE } \\
\text { Chow test }\end{array}$ & $\begin{array}{r}1,203.30^{* * *} \\
3.10^{* *}\end{array}$ & $689.54^{* * *}$ & $\begin{array}{r}82.71 * * * \\
1.81\end{array}$ & $224.89 * * *$ \\
\hline $\begin{array}{l}\text { Note: Canton and } \\
\text { standard errors tha } \\
\text { statistical significar } \\
\text { level). The number } \\
\text { Wald test has the } \\
\text { municipalities loca } \\
\text { baed regressio }\end{array}$ & $\begin{array}{l}\text { included. Cons } \\
\text { tering at the ca } \\
\text { ce at the } 10 \% \text { I } \\
\text { the estimated } p \\
\text { fixed effects a } \\
\text { eebt brake are }\end{array}$ & $\begin{array}{l}\text { own. The nu } \\
\text { I and correct } \\
0.05 \text { (signific } \\
\text { the fiscal ru } \\
\text { qual to zero. } \\
\text { ose of the ot }\end{array}$ & $\begin{array}{l}\text { eses indicat } \\
\text { asticity. Thes } \\
\text { vel), and } * * * \\
\text { the wild-clus } \\
\text { s the null hyp } \\
\text { ld and Chow }\end{array}$ & $\begin{array}{l}\text { nated t-stat } \\
\text { e used to de } \\
\text { gnificance a } \\
\text { ap-t proced } \\
\text { at the param } \\
\text { report test }\end{array}$ \\
\hline
\end{tabular}

\section{ROBUSTNESS CHECKS}

To check the robustness of the results we apply a large battery of tests: A first part addresses robustness of the estimated average treatment effect if we consider times of cantonal fiscal turmoil. Vertical shifts may occur more frequently if cantons face strong financial needs. In a second part, we investigate the robustness of the baseline results taking into account voter's preferences, direct democratic institutions, breaks in the time series, statistical outliers in the sample and the role of fixed effects. For reasons of clarity, we report only results regarding the first sample and the debt brake dummy and base our statistical inference exclusively on the more conservative wild-cluster bootstrapped p-values. ${ }^{22}$

\footnotetext{
${ }^{22}$ Similar findings obtain if we consider the second sample, the fiscal rule index and cluster-robust standard errors.
} 


\section{Part I: Vertical effects in times of fiscal shocks}

So far, the baseline findings provide little evidence of an average treatment effect, possibly because cantons regularly generate surpluses (Figure 4, left panel) with the result that budget rules only play a minor role. Thus, vertical effects of debt brakes might be more pronounced during times of fiscal stress. To investigate this possibility, we follow two distinct approaches:

First, we restrict our analysis to the fiscally eye-catching years 1990-1998 (Figure 4, left panel). The sub-period is characterized by economic turmoil and unbalanced cantonal budgets. Importantly, the five cantons (AR, FR, GR, SG, SO), which have been constrained by a debt brake during 1990-1998, accumulated deficits during most of the years (Figure 4, right panel). The situation is, however, different in Appenzell Outer-Rhodes in 1996. The canton generated a large surplus by selling its Cantonal Bank to the UBS.

Figure 4 Cantonal fiscal shocks (bars, left axis) and deficits (lines, right axis)

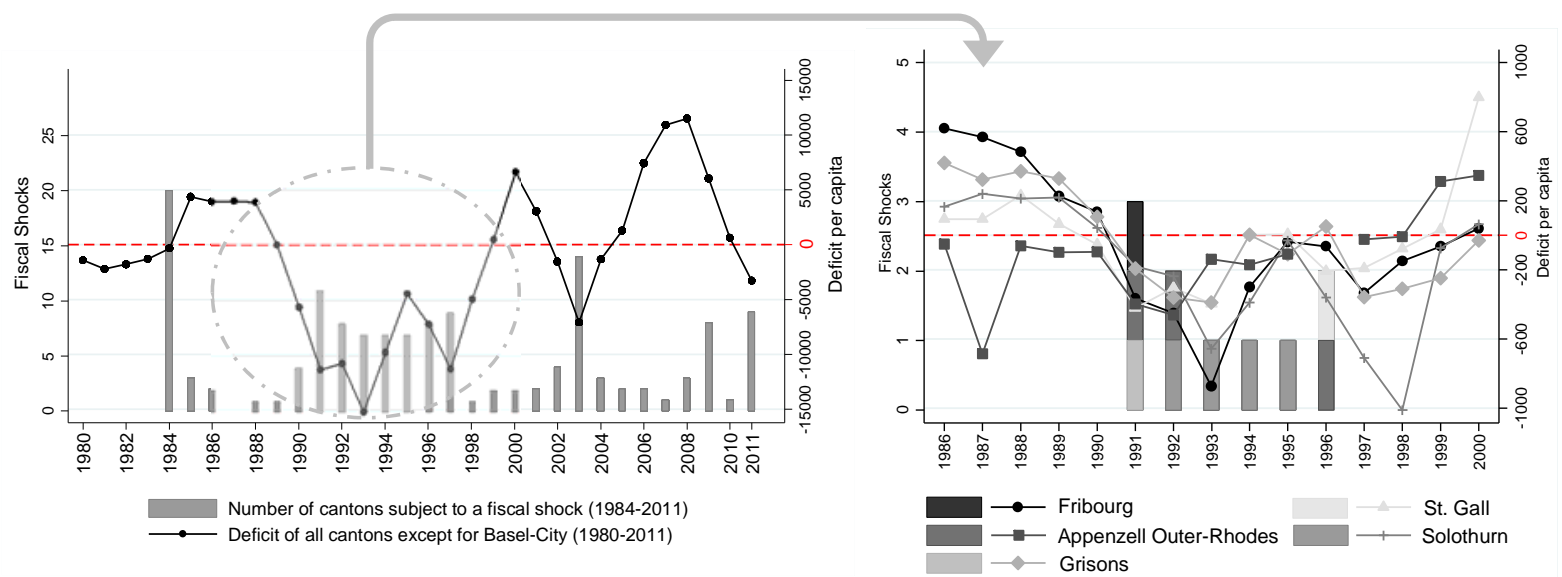

Note: Deficit is derived by subtracting real expenditures from real revenues. For scaling reasons, the right graph does not show the observation for Appenzell Outer-Rhodes in 1996.

In compliance with the baseline results, the debt brake variable keeps its negative sign in all equations except for debt if we restrict the analysis to the sub-period 1990-1998 (Table 6, upper panel). Interestingly, the corresponding coefficients are highly significant now. Thus, even in times of economic turmoil debt brakes do not induce cantonal governments to place fiscal burden on the local level. The results rather indicate that municipalities located in cantons with a debt brake have significantly lower expenditures, deficits and revenues, despite the fiscal stress at the cantonal level. While this approach is quite intuitive, the validity of the results is less pronounced than in the previous analysis as we observe only five cantons with a debt brake and quite a short period (255 observations in total). Moreover, deficits are only a crude indicator for fiscal shocks as deficits might not be unexpected but planned. 
A second approach mitigates these shortcomings by constructing a measure for fiscal shocks and taking a much longer period into account. To be precise, we draw on, e.g., Poterba (1994), Poterba and Rueben (1999, 2001), Lundberg (1997), Ratts $\varnothing$ (2004) and Ratts $\varnothing$ and Tovmo (2002) and define a fiscal shock in canton c in year $t$ as:

Fiscal Shock ${ }_{\mathrm{ct}}=\frac{\left[\left(\text { Expenditure }_{\mathrm{ct}}^{\text {actual }}-\text { Expenditure }_{\mathrm{ct}}^{\text {forecast }}\right)-\left(\text { Revenue }_{\mathrm{ct}}^{\mathrm{actual}}-\text { Revenue }_{\mathrm{ct}}^{\mathrm{forecast}}\right)\right]}{\text { Population }_{\mathrm{ct}}}$.

Thus, a positive fiscal shock indicates an unfavorable deficit shock, i.e. an unexpected shortfall of current revenue or an unexpected increase in current spending, respectively. Conversely, a fiscal shock takes a negative value in case of an unexpected favorable surplus shock. ${ }^{23}$ As cantons frequently generate surpluses, it is neither surprising that the mean of fiscal shocks is -0.158 (corresponding to a revenue shock) nor that 558 surplus shocks and only 242 deficit shocks are recorded. Similar to cantonal deficits, a cluster of unexpected deficit shocks can particularly be observed during the 1990s (Figure 4, left). However, during the period 19901998, three of the five fiscally constrained cantons (FR, GR, and SG) experienced only one fiscal shock (Figure 4, right). The small number of fiscal shocks in the five cantons during the period 1990-1998 further questions whether the above analysis is appropriate to reveal the effects of debt brakes during times of fiscal shocks.

Thus, in the second approach we interact the fiscal rule dummy with the indicator for fiscal shocks trying to clarify how changes in local finances and decentralization after a cantonal fiscal shock differ depending on the presence of a cantonal debt brake. Table 6 (lower panel) briefly summarizes the findings. The results broadly confirm our baseline estimates: While cantonal deficit shocks significantly increase local deficits when the corresponding canton is not constrained by a budget rule, the interaction term reveals the opposite (though insignificant) impact otherwise. With regard to the other dependent variables, cantonal fiscal shocks are not statistically significant. We conclude that even if cantonal governments are subject to a fiscal shock, they do not take any actions that burden local finances if a debt brake is in place. ${ }^{24}$

\footnotetext{
${ }^{23}$ Note, however, that a canton might face a shock while its books are eventually balanced. This could be the case if a canton expects a budget surplus (deficit) and faces a deficit (surplus) shock. The definition of a fiscal shock implicitly assumes that the fiscal year's budget forecasts are not (strategically) biased. We are grateful to Luechinger and Schaltegger (2013) for providing us with data on expected and actual current income and expenses for the years 1984-1998. From 1999 onwards, the data source is the Conference of Cantonal Ministers of Finance. ${ }^{24}$ As Brambor et al. (2006) note, insignificant interaction terms should not be taken as evidence for the absence of statistically meaningful effects. However, marginal effects are insignificant, too. Results available upon request.
} 

Robustness tests part I: Vertical effects in times of fiscal shocks

\begin{tabular}{|c|c|c|c|c|c|c|c|c|}
\hline \multicolumn{3}{|c|}{ Sample 1} & \multirow{2}{*}{$\begin{array}{r}\text { Expenditure } \\
-0.122^{* * *} \\
{[0002]}\end{array}$} & \multirow{2}{*}{$\begin{array}{r}\text { Revenue } \\
-0.067^{* * *} \\
{[0.004]}\end{array}$} & \multirow{2}{*}{$\begin{array}{r}\text { Debt } \\
0.076 \\
{[0.142]}\end{array}$} & \multirow{2}{*}{$\begin{array}{r}\text { Deficit } \\
-292.824^{* * *} \\
{[0.002]}\end{array}$} & \multirow{2}{*}{$\begin{array}{r}\text { Expend. } \\
\text { Decentr. } \\
-0.058^{* * *} \\
{[0.002]}\end{array}$} & \multirow{2}{*}{$\begin{array}{r}\text { Revenue } \\
\text { Decentr. } \\
-0.076^{* * *} \\
{[0.002]}\end{array}$} \\
\hline a) & $\begin{array}{l}\text { Sub-period, } \\
1990-1998\end{array}$ & Debt brake & & & & & & \\
\hline & & Controls & Yes & Yes & Yes & Yes & Yes & Yes \\
\hline & & Two-way fixed effects & Yes & Yes & Yes & Yes & Yes & Yes \\
\hline & & Adj. R2 & 0.13 & 0.22 & 0.20 & 0.22 & 0.42 & 0.40 \\
\hline & & $\mathrm{N}$ & 255 & 255 & 255 & 255 & 255 & 255 \\
\hline & & Cluster & 25 & 25 & 25 & 25 & 25 & 25 \\
\hline \multirow[t]{10}{*}{ b) } & $\begin{array}{l}\text { Fiscal shock, } \\
1984-2011\end{array}$ & Debt brake & $\begin{array}{c}-0.023 \\
{[0.462]}\end{array}$ & $\begin{array}{r}-0.014 \\
{[0.663]}\end{array}$ & $\begin{array}{r}-0.009 \\
{[0.823]}\end{array}$ & $\begin{array}{r}-65.447 \\
{[0.272]}\end{array}$ & $\begin{array}{c}-0.017 \\
{[0.130]}\end{array}$ & $\begin{array}{r}-0.020 \\
{[0.130]}\end{array}$ \\
\hline & & Deficit shock & -0.000 & -0.013 & 0.003 & $73.363^{* *}$ & -0.002 & -0.000 \\
\hline & & & {$[0.987]$} & {$[0.416]$} & {$[0.735]$} & [0.018] & {$[0.336]$} & [0.999] \\
\hline & & Debt brake* Fiscal shock & -0.002 & -0.002 & -0.002 & -16.920 & -0.000 & 0.001 \\
\hline & & & [0.905] & [0.859] & [0.999] & {$[0.787]$} & [0.917] & [0.807] \\
\hline & & Controls & Yes & Yes & Yes & Yes & Yes & Yes \\
\hline & & Two-way fixed effects & Yes & Yes & Yes & Yes & Yes & Yes \\
\hline & & Adj. R2 & 0.47 & 0.48 & 0.44 & 0.25 & 0.62 & 0.59 \\
\hline & & $\mathrm{N}$ & 700 & 700 & 700 & 700 & 700 & 700 \\
\hline & & Cluster & 25 & 25 & 25 & 25 & 25 & 25 \\
\hline
\end{tabular}

Note: Besides the variables shown, we employ all controls as in the corresponding baseline regression of sample 1 (Table 3 and 5 ). Due to data limitations, public debt is only analyzed during the years 1990-2009. The numbers in brackets indicate the estimated p-values using the wildcluster bootstrap-t procedure. These values are used to determine statistical significance: ${ }^{*} p<0.1$ (significance at the $10 \%$ level), ${ }^{* *} p<0.05$ (significance at the $5 \%$ level), and ${ }^{* *} p<0.01$ (significance at the $1 \%$ level). Full regression bodies available upon request.

\section{Part II: General modifications}

The second part of the robustness analysis comprises six different kinds of modifications:

First, we examine several sub-periods in order to address structural breaks in the time series in 1990 and 2008, respectively, and to check whether the effect of cantonal debt brakes varies between "early" and "late" adopters. Since we employ fixed effects and the institutional variation is quite low during the "early" sub-period, the validity of the results for the years 1980-1989 is limited.

Second, additional institutional controls are employed. To capture the extent of direct democracy, three indicators are used: A dummy which equals one if cantonal spending projects require an approval by the majority of voters, a measure of the spending thresholds (in million Swiss Francs) that trigger cantonal mandatory referenda and a variable indicating the number of signatures per capita required to launch a cantonal initiative. In a next step, we employ the share of own local revenues from total local revenues to control for the influence of grants. The analysis is restricted to the period 19902011 as earlier data on own revenues is not available.

Third, we address the influence of voters' preferences. As discussed in Section 4, we estimate a fiscally conservative and non-conservative sub-sample, respectively. 
Fourth, the influence of outliers is examined. The presence of outliers might lead to erroneous estimates of the standard errors as OLS weighs larger residuals more heavily and assumes normally distributed error terms. Due to federal asymmetries and interjurisdictional differences in areas such as geography, urbanization, industrialization and population size the issue of outliers is likely to be of relevance in our case. While problems can be mitigated by a large sample and log transformation, we further address the issue by estimating a median regression. ${ }^{25}$ Alternatively, outliers and bad leverage points are identified by Cook's distance, i.e., the accumulated change in the estimated coefficients if each observation is excluded. We follow a rule of thumb and discard observation with a Cook's distance greater than 4/N (where $\mathrm{N}$ is the number of observations in the sample).

Fifth, we test the robustness of baseline estimates to the exclusion of fixed effects as these might hide the impact of an institutional variable and render it insignificant. However, the debt brake dummy varies quite across time and cantons (Figure 2), such that the exclusion of fixed effects is problematic: One the one hand, the issue of omitted variables arises; on the other hand, cantonal asymmetries are not adequately taken into account. Instead, fixed effects may be necessary to mitigate the impact of block concentrated outliers, respectively. This is supported by the Wald tests as they suggest including two-way fixed effects (see baseline regressions).

Sixth, the measurement of the fiscal rule index is modified. Since the fiscal rule index implies a linear effect of cantonal debt brakes, we replace it by a dummy for each level of stringency. Such a specification allows for a non-linear, more flexible impact. We do not report the estimation results for a strong debt brake (i.e., with an index value of 3) as the results are only based on three observations (2009-2011) for Basel-County. While St. Gall and Fribourg also have a strong debt brake, the observations are dropped since we employ fixed effects and their debt brakes do not change across time.

The results are briefly summarized in Table 7. While the baseline results are largely confirmed, three issues are striking: First, the sign of the debt brake dummy changes frequently in the debt equations, though statistical significance is only obtained in one case at the $10 \%$ level. Second,

\footnotetext{
${ }^{25}$ It estimates the median ( 0.5 quantile) of the dependent variable rather than the mean in ordinary regression. Thereby it minimizes the sum of the absolute residuals. Median regression is, thus, more robust to outliers in observations and the results are valid even if the errors are not independent and identically distributed.
} 
the exclusion of cantonal fixed effects results in a positive impact of the debt brake dummy in most equations, without reaching any conventional significance level however. In any case, these estimates need to be taken with a great deal of caution as Wald tests and cantonal asymmetries suggest including fixed effects.

Table $7 \quad$ Robustness tests part II: Further modifications, sample 1

\begin{tabular}{|c|c|c|c|c|c|c|c|}
\hline Sample 1 & & Expend. & Revenue & Debt $^{3)}$ & Deficit & $\begin{array}{l}\text { Exp. } \\
\text { dec. }\end{array}$ & $\begin{array}{l}\text { Rev. } \\
\text { dec. }\end{array}$ \\
\hline 1) Sub-periods & $\begin{array}{l}\text { a) } 1980-1989 \\
\text { b) } 1990-2011 \\
\text { c) } 1990-2008\end{array}$ & $\begin{array}{l}\text { Confirm } \\
\text { Confirm } \\
\text { Confirm }\end{array}$ & $\begin{array}{l}\text { Confirm } \\
\text { Confirm } \\
\text { Confirm }\end{array}$ & $\begin{array}{l}\mathrm{n} / \mathrm{a} \\
\mathrm{n} / \mathrm{a} \\
+/-\end{array}$ & $\begin{array}{r}\text { Confirm } \\
* \\
\text { Confirm }\end{array}$ & $\begin{array}{r}+/- \\
\text { Confirm } \\
\text { Confirm }\end{array}$ & $\begin{array}{l}\text { Confirm } \\
\text { Confirm } \\
\text { Confirm }\end{array}$ \\
\hline $\begin{array}{l}\text { 2) Institutional } \\
\text { controls }\end{array}$ & $\begin{array}{l}\text { a) Direct democracy } 1980-2005 \\
\text { b) Share own revenues } 1990-2011\end{array}$ & $\begin{array}{l}\text { Confirm } \\
\text { Confirm }\end{array}$ & $\begin{array}{l}\text { Confirm } \\
\text { Confirm }\end{array}$ & $\begin{array}{r}+/-^{*} \\
\text { Confirm }\end{array}$ & $\begin{array}{r}\text { Confirm } \\
*\end{array}$ & $\begin{array}{r}* * * \\
\text { Confirm }\end{array}$ & $\begin{array}{r}* * \\
\text { Confirm }\end{array}$ \\
\hline $\begin{array}{l}\text { 3) Voters' } \\
\text { preferences }\end{array}$ & $\begin{array}{l}\text { a) Conservative cantons } 1980-2011 \\
\text { b) Non-conservative cantons } 1980-2011\end{array}$ & $\begin{array}{l}\text { Confirm } \\
\text { Confirm }\end{array}$ & $\begin{array}{l}\text { Confirm } \\
\text { Confirm }\end{array}$ & $\begin{array}{r}+/- \\
*\end{array}$ & $\begin{array}{r}\text { Confirm } \\
* *\end{array}$ & $\begin{array}{l}\text { Confirm } \\
\text { Confirm }\end{array}$ & $\begin{array}{l}\text { Confirm } \\
\text { Confirm }\end{array}$ \\
\hline 4) Outliers & $\begin{array}{l}\text { a) Median regression } 1980-2011^{11} \\
\text { b) Exclusion of outliers } 1980-2011\end{array}$ & $\begin{array}{l}\text { Confirm } \\
\text { Confirm }\end{array}$ & $\begin{array}{l}\text { Confirm } \\
\text { Confirm }\end{array}$ & $\begin{array}{l}+/- \\
+/-\end{array}$ & $\begin{array}{l}\text { Confirm } \\
\text { Confirm }\end{array}$ & Confirm & $\begin{array}{l}* \\
*\end{array}$ \\
\hline $\begin{array}{l}\text { 5) Exclusion of } \\
\text { fixed effects }\end{array}$ & $\begin{array}{l}\text { a) Only canton fixed effects, } 1980-2011 \\
\text { b) Only year fixed effects, } 1980-2011 \\
\text { c) No fixed effects, } 1980-2011\end{array}$ & $\begin{array}{l}* \\
+/- \\
+/-\end{array}$ & $\begin{array}{r}\text { Confirm } \\
+/- \\
+/-\end{array}$ & $\begin{array}{r}\text { Confirm } \\
+/- \\
+/-\end{array}$ & $\begin{array}{r}\text { Confirm } \\
+/- \\
\text { Confirm }\end{array}$ & $\begin{array}{l}+/- \\
* * \\
+/-\end{array}$ & $\begin{array}{r}* * \\
+/- \\
\text { Confirm }\end{array}$ \\
\hline $\begin{array}{l}\text { 6) Measurement } \\
\text { of rule index }\end{array}$ & $\begin{array}{l}\text { a) Dummies instead of fiscal rule index }{ }^{2)} \\
\qquad \begin{array}{r}\text { Index }=1 \\
\text { Index }=2\end{array}\end{array}$ & $\begin{array}{l}\text { Confirm } \\
\text { Confirm }\end{array}$ & $\begin{array}{l}\text { Confirm } \\
\text { Confirm }\end{array}$ & $\begin{array}{r}+/- \\
\text { Confirm }\end{array}$ & $\begin{array}{r}+/- \\
\text { Confirm }\end{array}$ & $\begin{array}{l}\text { Confirm } \\
\text { Confirm }\end{array}$ & $\begin{array}{l}\text { Confirm } \\
\text { Confirm }\end{array}$ \\
\hline
\end{tabular}

Note: "Confirm" means that the debt brake dummy keeps the same sign as in the baseline regression (i.e. negative) and that it does not reach statistical significance at any conventional level based on $p$-values calculated by the wild-cluster bootstrap-t-procedure. If the variable has a different sign than in our baseline estimation it is indicated by $+/$. If the variables reach statistical significance it is indicated by: $*(p<0.1), * *(p<0.05)$ and $* * *(p<0.01)$. OLS regression including two-way fixed effects and all controls as employed in the baseline regression (Table 3 and 5). Full regression bodies available upon request. 1) Inference based on cluster-robust standard errors. 2) Since the dummy for strong cantonal debt brakes (index $=3$ ) varies hardly over time it is not reported. 3) Deviating periods since debt data is only available between 1990 and 2009.

Third, cantonal budget rules have a (highly) significant effect on spending and revenue decentralization if outliers weigh less heavily according to the median regressions or if we additionally control for the extent of cantonal direct democracy, respectively. Since direct democratic institutions are key elements of the fiscal framework in Switzerland, this is a highly important piece of evidence. A closer examination reveals that cantonal signature requirements that launch a popular initiative have a highly significant negative effect on local spending and revenue, respectively (Table A.6). Similar results obtain for the presence of mandatory referenda in a canton. While the spending threshold that triggers a referendum is not significant for local finances, it significantly reduces fiscal decentralization (Table A.7). On the contrary, Funk and Gathmann (2011) find little evidence for vertical effects of cantonal direct democratic institutions and Feld et al. (2008) conclude that direct democracy at the cantonal level has a restrictive impact on fiscal centralization.

Interestingly, the results for jurisdictions with fiscally conservative voters are close to the baseline results. In fiscally non-conservative jurisdictions, cantonal budget rules have a significantly negative effect on local deficits ( $5 \%$ level) and on debt ( $10 \%$ level). The results tend 
to suggest that debt brakes spill over from the cantonal to the municipal level if local voters exercise little consolidation pressure. It should, however, be noted that the validity of this specification is restricted as the regression covers only eight fiscally non-conservative cantons of which none had a debt brake in place before 2005.

We conclude that the robustness tests produce some variation in the results, while the baseline findings still seem robust to most specifications. In fact, all robustness checks confirm a negative impact of cantonal fiscal rules on local spending, revenue and fiscal decentralization (except for one case). However, statistical significance is only obtained if we restrict our analysis to the sub-period 1990-1998. With regard to local debt and deficits the estimated sign of the debt brake coefficient changes in some specifications, in particular, when institutions of direct democracy are controlled for or fixed effects are not considered. Once more, the sub-period 1990-1998 reveals a statistically significant impact of cantonal budget rules on local deficits.

\section{DISCUSSION AND CONCLUSION}

Most empirical studies on fiscal rules focus on effects within the constrained entity such as their impact on intra-jurisdictional finances, fiscal sustainability, macroeconomic stabilization and creative accounting, respectively. However, there are good reasons that fiscal rules also exhibit vertical effects on the finances of other levels of government even though those other levels are actually not covered by the rule. While upward effects might be hard to push through and are likely to be accompanied with a loss in decision-making power, downward effects seem to be much more attractive. In fact, municipal governments have contended that fiscal rules on an upper level of government burdened their finances.

To study this question, this paper examines vertical effects of Swiss cantonal debt brakes on municipal expenditure, revenue, debt, deficits and fiscal decentralization, respectively. As the cantonal fiscal rules vary substantially across time and cantons, a Difference-in-Differences design can be employed. In doing so we exploit a sample of cantonal aggregated data of (almost) all municipalities (1980-2011) and a sample of disaggregated data of the 139 largest cities (1982-2007). On the one hand, we add to the existing literature on fiscal rules and on the other hand to research on vertical effects of institutions. While previous studies suggest that debt brakes are strong enough to trigger fiscal consequences at the cantonal level (e.g., Feld and Kirchgässner, 2008; Krogstrup and Wälti, 2008), we provide evidence that Swiss cantonal debt brakes do not induce politicians to take actions that significantly burden finances at the 
local level. As cantons frequently generate surpluses, it could be argued that cantonal governments have few incentives to circumvent their budget constraints by placing an additional fiscal burden on the municipal level. Yet, debt brakes do not lead to a burdening of municipal finances even if cantons experience unfavorable deficits shocks.

Our findings raise the question whether cantons do simply not transmit fiscal burdens or municipalities resist such a policy. Since our evidence suggests that cantonal debt brakes do not increase local expenditures, we have some hints that cantons do indeed not transmit fiscal burdens. In fact, it rather seems likely that cantonal governments take their responsibility for local finances more seriously when they are constrained by a debt brake. That debt brakes lead to increased cantonal prudence regarding the local level could be explained by the fact that cantons want to hedge the risk of potential future bailouts that must be rather financed by own means (instead of debt) if a debt brake is in place.

While our findings are broadly in line with cursory evidence for Switzerland provided by Feld and Kirchgässner (2008), earlier studies for the US suggest that fiscal rules in US states burden local finances (e.g., von Hagen 1992; Kiewiet and Szakaly, 1996). We take this as a sign that our results for cantonal debt brakes are, at least party, driven by a well-designed and incentivebased fiscal framework in Switzerland. Yet, much research remains to be done on the exact vertical transmission mechanisms in different institutional settings.

\section{REFERENCES}

Abrams, B.A. and W.R. Dougan (1986), The Effects of Constitutional Restraints on Governmental Spending, Public Choice 9, 101-116.

Advisory Commission on Intergovernmental Relations (ACIR) (1987), Fiscal Discipline in the Federal System: Experience of the States, Washington, D.C.

Alesina, A., R. Hausmann, R. Hommes and E. Stein (1999), Budget Institutions and Fiscal Performance in Latin America, Journal of Development Economics 59, 253-273.

Angrist, J.D. and J.-S. Pischke (2009), Mostly Harmless Econometrics, Princeton University Press, Princeton et al.

Ayuso-i-Casals, J., D.G. Hernandez, L. Moulin and A. Turrini (2007), Beyond the SGP: Features and Effects of EU National-Level Fiscal Rules, in: J. Ayuso-i-Casals, S. Deroose, E. Flores and L. Moulin (eds.), The Role of Fiscal Rules and Institutions in Shaping Budgetary Outcomes, pp. 191-242, European Commission Economic Papers 275.

Balduzzi, P. and V. Grembi (2011), Fiscal Rules and Window Dressing in Italian Municipalities, Giornale degli Economisti 70, 97-122.

Baskaran, T. (2011), Fiscal Decentralization, Ideology, and the Size of the Public Sector, European Journal of Political Economy 27, 485-506. 
Bennett, J.T. and T.J. DiLorenzo (1983), Underground Government: The Off-Budget Public Sector, Cato Institute, Washington, D.C.

Bernoth, K. and G.B. Wolff (2008), Fool the Markets? Creative Accounting, Fiscal Transparency and Sovereign Risk Premia, Scottish Journal of Political Economy 55, 465-487.

Bertrand, M., E. Duflo and S. Mullainathan (2004), How Much Should We Trust Differences-inDifferences Estimates?, Quarterly Journal of Economics 119, 249-275.

Briffault, R. (1996), Balancing Acts: The Reality Behind State Balanced Budget Requirements, Twentieth Century Fund, New York.

Brülhart, M. and M. Jametti (2006), Vertical versus Horizontal Tax Externalities: An Empirical Test, Journal of Public Economics 90, 2027-2062.

Bunch, B.S. (1991), The Effect of Constitutional Debt Limits on State Governments' Use of Public Authorities, Public Choice 68, 57-69.

Brambor, T., W.R. Clark and M. Golder (2006), Understanding Interaction Models: Improving Empirical Analyses, Political Analysis 14, 63-82.

Burret, H.T. and L.P. Feld (2014), A Note on Budget Rules and Fiscal Federalism, CESifo DICE Report 1/2014, 3-11.

Buti, M., J.M. Martins and A. Turrini (2007), From Deficits to Debt and Back: Political Incentives under Numerical Fiscal Rules, CESifo Economic Studies 53, 115-152.

Cameron A.C. and D.L. Miller (2013), A Practitioner's Guide to Cluster-Robust Inference, downloadable from (accessed 20. August 2013): http://cameron.econ.ucdavis.edu/research/papers.html, forthcoming in Journal of Human Resources Spring 2015.

Cameron, A.C., J.B. Gelbach and D.L. Miller (2008), Bootstrap-based Improvements for Inference with Clustered Errors, Review of Economics and Statistics 90, 414-427.

Chatagny, F. (2013), Incentive Effects of Fiscal Rules on the Finance Minister's Behaviour: Evidence from Revenue Projections in Swiss Cantons, KOF Working Papers 347.

Conference of Cantonal Ministers of Finance (2012), Finanzpolitische Regeln der Kantone: Ausgaben-, Defizit- und Schuldenbremsen zum Stand: 18. December 2012, downloadable from (accessed 20 August 2013): http://www.fdk-cdf.ch/121218 hh-regeln update def d.pdf.

Conference of Cantonal Ministers of Finance (2013), Handbook on the Harmonized Accounting Model for the Cantons and Communes (HAM2), Solothurn.

Costello, A.M., R. Petacchi and J.P. Weber (2012), The Hidden Consequences of Balanced Budget Requirements, MIT Sloan School of Management Working Paper.

Council of Europe (1997), Local Finance in Europe, Study Series Local and Regional Authorities in Europe 61, Council of Europe Publishing, Strasbourg.

Dafflon, B. and F. Pujol (2001), Fiscal Preferences and Fiscal Performance: Swiss Cantonal Evidence, International Public Management Review 2, 54-76.

Dafflon, B. and S. Rossi (1999), Public Accounting Fudges Towards EMU: A First Empirical Survey and some Public Choice Considerations, Public Choice 101, 59-84.

De Haan, J. and J.-E. Sturm (1994), Political and Institutional Determinants of Fiscal Policy in the European Community, Public Choice 80, 157-172.

De Haan, J., W. Moessen and B. Volkerink (1999), Budgetary Procedures: Aspects and Changes: New Evidence for some European countries, in: J.M. Poterba and J. von Hagen (eds.), Fiscal Institutions and Fiscal Performance, pp. 265-300, University of Chicago Press, Chicago.

Debrun, X., L. Moulin, A. Turrini, J. Ayuso-i-Casals and M.S. Kumar (2008), Tied to the Mast? National Fiscal Rules in the European Union, Economic Policy 23, 297-362.

Feld, L.P. and G. Kirchgässner (2001a), The Political Economy of Direct Legislation: Direct Democracy and Local Decision-Making, Economic Policy 16, 329-367. 
Feld, L.P. and G. Kirchgässner (2001b), Does Direct Democracy Reduce Public Debt? Evidence from Swiss Municipalities, Public Choice 109, 347-370.

Feld, L.P. and G. Kirchgässner (2008), On the Effectiveness of Debt Brakes: The Swiss Experience, in: R. Neck and J.-E. Sturm (eds.), Sustainability of Public Debt, pp. 223-255, MIT Press, Cambridge/London.

Feld, L.P., G. Kirchgässner and C.A. Schaltegger (2010), Decentralized Taxation and the Size of Government: Evidence from Swiss State and Local Governments, Southern Economic Journal 77, 27-48.

Feld, L.P., G. Kirchgässner and C.A. Schaltegger (2011), Municipal Debt in Switzerland: New Empirical Results, Public Choice 149, 49-64.

Feld, L.P., C.A. Schaltegger and J. Schnellenbach (2008), On Government Centralization and Fiscal Referendums, European Economic Review 52, 611-645.

Feld, L.P., A. Kalb, M.-D. Moessinger and S. Osterloh (2013), Sovereign Bond Market Reactions to Fiscal Rules and No-Bailout Clauses: The Swiss Experience, CESifo Working Paper Series 4195.

Finances Publiques (2004), Bericht über die Evaluation Einhaltung der Minimalanforderungen an die kantonale Aufsicht über die Gemeindefinanzen durch die Schweizer Kantone, 20. October 2004.

Foremny, D. (2014), Sub-national Deficits in European Countries: The Impact of Fiscal Rules and Tax Autonomy, European Journal of Political Economy 34, 86-110.

Funk, P. and C. Gathmann (2011), Does Direct Democracy Reduce the Size of Government? New Evidence from Historical Data, 1890-2000, Economic Journal 121, 1252-1280.

General Accounting Office (GAO) (1993), Balanced Budget Requirements: State Experiences and Implications for the Federal Government, Washington, D.C.

German Association of Cities (2011), Städte fordern Schutzschirm wegen Schuldenbremse der Länder, Press Release (3. May 2011), downloaded from (accessed 26 June 2012): http://www.staedtetag.de/presse/mitteilungen/057674/index.html.

Geschäftsprüfungskommission des Grossen Rates (1999), Sonderbericht über die Dossiers Leukerbad und Casino de Saxon, downloadable from (accessed 6 February 2012): http://www.vs.ch/Press/DS 3/PU-1999-02-16-1652/de/rap cg d.pdf.

Gollwitzer, S. (2010), Budget Institutions and Fiscal Performance in Africa, Journal of African Economies 20, 111-152.

Guichard, S., M. Kennedy, E. Wurzel and C. André (2007), What Promotes Fiscal Consolidation: OECD Country Experiences, OECD Economics Departments Working Paper 553.

Heins, A.J. (1963), Constitutional Restrictions against State Debt, University of Wisconsin Press, Madison.

Hou, Y. and D.L. Smith (2010), Do State Balanced Budget Requirements Matter? Testing Two Explanatory Frameworks, Public Choice 145, 57-79.

Imbeau, L.M. and G. Tellier (2004), The Political-Economy of Budget Deficits in the Canadian Provinces, 1968-2000, in: L.M. Imbeau and F. Pétry (eds.), Politics, Institutions, and Fiscal Policy: Deficits and Surpluses in Federated States, pp. 89-111 Lexington Books, Lanham.

Irwin T. (2012), Accounting Devices and Fiscal Illusions, International Monetary Fund Discussion Note 12/02, Washington.

Kézdi, G. (2004), Robust Standard Error Estimation in Fixed-Effects Panel Models, Hungarian Statistical Review Special 9, 96-116.

Kiewiet, D.R. and K. Szakaly (1996), Constitutional Limitations on Borrowing: An Analysis of State Bonded Indebtedness, Journal of Law, Economics \& Organization 12, 62-97.

Kirchgässner, G. (2013), Fiscal Institutions at the Cantonal Level in Switzerland, Swiss Journal of Economics and Statistics 149, 139-166.

Koen, V. and P. van den Noord (2005), Fiscal Gimmickry in Europe: One-Off Measures and Creative Accounting, OECD Economics Department Working Papers 417. 
Krogstrup, S. and S. Wälti (2008), Do Fiscal Rules Cause Budgetary Outcomes?, Public Choice 136, 128138.

Lenk, T.O. Rottmann and M. Kuntze (2012), Auswirkungen der Schuldenbremse auf die kommunale Ebene, Commerzbank AG: Frankfurt am Main.

Luechinger, S. and C.A. Schaltegger (2013), Fiscal Rules, Budget Deficits and Budget Projections, International Tax and Public Finance 20, 785-805.

Lundberg, J. (1997), Short Run Responses to Fiscal Shocks: Evidence from Swedish Municipalities, Department of Economics, Umeå University, Sweden.

Mackinnon, J. and M. Webb (2014), Wild Bootstrap Inference for Wildly Different Cluster Sizes, Queen's Economics Department Working Paper 1314

Mahdavi, S. and J. Westerlund (2011), Fiscal Stringency and Fiscal Sustainability: Panel Evidence from the American State and Local Governments, Journal of Policy Modelling 33, 953-969.

Malde, B. (2012), Bootwildct: Ado file for Stata, Economic and Social Research Council.

Marneffe, W., B. Van Aarle, W. Van der Wielen and L. Vereeck (2011), The Impact of Fiscal Rules on Public Finances in the Euro Area, CESifo DICE Report 3/2011, 18-25.

Matsusaka, J.G. (1995), Fiscal Effects of the Voter Initiative: Evidence from the Last 30 Years, Journal of Political Economy 103, 587-623.

Meyer, K. (2011), Gemeindeautonomie im Wandel: Eine Studie zu Art. 50 Abs. 1 BV unter Berücksichtigung der Europäischen Charta der Gemeindeautonomie, Books on Demand GmbH, Norderstedt.

Milesi-Ferretti, G. and K. Moriyama (2006), Fiscal Adjustment in EU Countries: A Balance Sheet Approach, Journal of Banking \& Finance 30, 3281-3298.

Mitchell, W.E. (1967), The Effectiveness of Debt Limits on State and Local Government Borrowing, The Bulletin 45, Institute of Finance, New York University, New York.

Neue Zürcher Zeitung (NZZ) (2004), Haushaltssanierung dank Lastenverschiebung?, 6 March 2004, downloadable from $\quad$ (accessed 6 February 2014): http://www.nzz.ch/aktuell/startseite/article9GBKJ-1.223921.

New, M.J. (2001), Limiting Government through Direct Democracy: The Case of State Tax and Expenditure Limitations, Cato Policy Analysis 420.

Nice, D.C. (1991), The Impact of State Policies to Limit Debt Financing, Publius 21, 69-82.

Nichols, A. and M.E. Schaffer (2007), Clustered standard Errors in Stata, United Kingdom Stata Users' Group Meetings 2007, Stata Users Group.

Pesaran, M.H. (2004), General Diagnostic Tests for Cross Section Dependence in Panels, CESifo Working Paper Series 1229.

Pogue, T.F. (1970), The Effect of Debt Limits: Some New Evidence, National Tax Journal 23, 36-49.

Poterba, J.M. (1994), State Responses to Fiscal Crisis: The Effects of Budgetary Institutions and Politics, Journal of Political Economy 102, 799-821.

Poterba, J.M. (1996), Budget Institutions and Fiscal Policy in the U.S. States, American Economic Review $86,395-400$.

Poterba, J.M. (1997), Do Budget Rules Work?, in: A.J. Auerbach (ed.), Fiscal Policy: Lessons from Economic Research, pp. 53-86, MIT Press, Cambridge.

Poterba, J.M. and K.S. Rueben (1999), Fiscal Rules and State Borrowing Costs: Evidence from California and Other States, Public Policy Institute of California, San Francisco.

Poterba, J.M. and K.S. Rueben (2001), Fiscal News, State Budget Rules, and Tax-Exempt Bond Yields, Journal of Urban Economics 50, 537-562.

Ratchford, B.U. (1941), American State Debts, Duke University Press, Durham, NC.

Ratts $\varnothing$, J. (2004), Fiscal Adjustment under Centralized Federalism: Empirical Evaluation of the Response to Budgetary Shocks, FinanzArchiv (Public Finance Analysis) 60, 240-261. 
Ratts $\varnothing$, J. and P. Tovmo (2002), Fiscal Discipline and Asymmetric Adjustment of Revenues and Expenditures: Local Government Responses to Shocks in Denmark, Public Finance Review 30, 208-234.

Reuter, W.H. (2014), National Numerical Fiscal Rules: Not Complied With, But Still Effective?, Paper presented at the 2014 Meeting of the European Public Choice Society in Cambridge.

Rogers, W.H. (1993), Regression Standard Errors in Clustered Samples, Stata Technical Bulletin 13, 1923.

Roubini, N. and J.D. Sachs (1989a), Political and Economic Determinants of Budget Deficits in the Industrial Democracies, European Economic Review 33, 903-938.

Roubini, N. and J.D. Sachs (1989b), Government Spending and Budget Deficits in the Industrial Countries, Economic Policy 8, 99-132.

Rühli, L. (2013), Irrgarten Finanzausgleich: Wege zu mehr Effizienz bei der interkommunalen Solidarität, Avenir Suisse, Zurich.

Schaltegger, C.A. (2002), Budgetregeln und ihre Wirkung auf die öffentlichen Haushalte: Empirische Ergebnisse aus den US-Bundesstaaten und den Schweizer Kantonen, Schmollers Jahrbuch 122, 369-413.

Shadbegian, R.J. (1996), Do Tax and Expenditure Limitations Affect the Size and Growth of State Government?, Contemporary Economic Policy 14, 22-35.

Singh, R. and A. Plekhanov (2006), How Should Subnational Government Borrowing be Regulated? Some Cross-Country Empirical Evidence, International Monetary Fund Staff Papers 53, 426-452.

Sørensen, B.E., L. Wu and O. Yosha (2001), Output Fluctuations and Fiscal Policy: U.S. State and Local Governments 1978-1994, European Economic Review 45, 1271-1310.

Stansel, D. (1994), Taming Leviathan: Are Tax and Spending Limits the Answer?, Cato Policy Analysis 213.

Stauffer, T.P. (2001), Instrumente des Haushaltsausgleichs: Ökonomische Analyse und rechtliche Umsetzung, Helbing und Lichtenhahn, Basel.

Steiner, R., J. Fiechter and C. Kaiser (2012), Gemeindebefragung 2009/2010: Zustand der Gemeinden des Kantons Zürich, KPM-Verlag, Bern.

Swiss Federal Chancellery (2007), Auf eine farbige Schweiz, Bern.

Swiss Federal Chancellery (2011), In der Kürze liegt die Würze, Bern.

Verband Züricher Finanzfachleute (VZF) (2011), Spitalplanungs- und finanzierungsgesetz: Folgen für Gemeinden, Drehscheibe 11/2, 1-3.

Volkerink, B. and J. De Haan (2001), Fragmented Government Effects on Fiscal Policy: New Evidence, Public Choice 109, 221-242.

Von Hagen, J. (1991), A Note on the Empirical Effectiveness of Formal Fiscal Restraints, Journal of Public Economics 44, 199-210.

Von Hagen, J. (1992), Fiscal Arrangements in a Monetary Union: Evidence from the U.S., in: D.E. Fair and C. de Boissieu (eds.), Fiscal Policy, Taxation and the Financial System in an Increasingly Integrated Europe, pp. 337-360, Kluwer Academic Publishers, Dordrecht.

Von Hagen, J. and G.B. Wolff (2006), What do Deficits tell us About Debt? Empirical Evidence on Creative Accounting with Fiscal Rules in the EU, Journal of Banking \& Finance 30, 3259-3279.

Yerly, N. (2013), The Political Economy of Budget Rules in the Twenty-six Swiss Cantons: Institutional Analysis, Preferences and Performances, Doctoral Thesis Presented to the Faculty of Economic and Social Sciences, University of Fribourg, Switzerland. 


\section{APPENDIX}

Table A.1

Descriptive statistics in total and by institutional regime, whole period

Dependent variables SAMPLE 1 Expenditure per capita (log)

Revenue per capita (log)

Debt per capita (lo

Deficit per capita

Expenditure decentralization

Revenue decentralization

Spending categories per capita (log)

Explanatory variables SAMPLE 1

Debt brake dummy

Debt brake index

Relative income

Income per capita (log)

Unemployment rate

Population (log)

Share own revenue

Share old

Share young

Spending threshold for referenda

Spending threshold for referenda

Signature requirement for initiatives

Mandatory referendum dummy

\section{Dependent variables SAMPLE}

Expenditure per capita (log)

Revenue per capita (log)

Debt per capita (log)

Deficit per capita

Spending categories per capita (log)

Explanatory variables SAMPLE 2

Relative incom

Income per capita (log)

Unemployment rate

Population (log)

Share own revenue

Share old

Share young

Coalition government

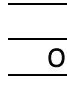

\begin{tabular}{rrrrr}
\hline \multicolumn{5}{c}{ Total } \\
\hline Obs & Mean & \multicolumn{1}{c}{ SD } & \multicolumn{1}{c}{ Min } & Max \\
\hline & & & & \\
800 & 8.469 & 0.253 & 7.782 & 9.106 \\
800 & 8.466 & 0.250 & 7.430 & 9.057 \\
550 & 8.522 & 0.493 & 6.439 & 9.350 \\
800 & 18.106 & 261.200 & -924.965 & $2,536.192$ \\
800 & 0.401 & 0.085 & 0.169 & 0.541 \\
800 & 0.400 & 0.084 & 0.184 & 0.543
\end{tabular}

\begin{tabular}{rrr}
\hline \multicolumn{3}{c}{ No debt brake $^{1)}$} \\
\hline Obs & \multicolumn{1}{c}{ Mean } & \multicolumn{1}{c}{ SD } \\
\hline & & \\
588 & 8.442 & 0.258 \\
588 & 8.436 & 0.254 \\
364 & 8.482 & 0.558 \\
588 & 32.321 & 264.464 \\
588 & 0.399 & 0.091 \\
588 & 0.399 & 0.089
\end{tabular}

\begin{tabular}{lrrr}
\hline \multicolumn{4}{c}{ Debt brake $^{1)}$} \\
\hline Obs & \multicolumn{1}{c}{ Mean } & \multicolumn{1}{c}{ SD } & p-value ${ }^{2)}$ \\
\hline & & & \\
212 & 8.546 & 0.221 & 0.000 \\
212 & 8.550 & 0.217 & 0.000 \\
186 & 8.601 & 0.316 & 0.007 \\
212 & -21.321 & 248.295 & 0.010 \\
212 & 0.406 & 0.066 & 0.309 \\
212 & 0.403 & 0.065 & 0.641
\end{tabular}

\begin{tabular}{|c|c|c|c|c|c|c|c|c|c|c|c|}
\hline 800 & 0.265 & 0.442 & 0.000 & 1.000 & & & & & & & \\
\hline 800 & 0.541 & 0.985 & 0.000 & 3.000 & & & & & & & \\
\hline 800 & 1.000 & 0.168 & 0.766 & 1.685 & 588 & 1.014 & 0.182 & 212 & 0.961 & 0.113 & 0.000 \\
\hline 800 & 3.340 & 0.189 & 2.871 & 3.984 & 588 & 3.331 & 0.202 & 212 & 3.365 & 0.146 & 0.026 \\
\hline 800 & 0.021 & 0.017 & 0.000 & 0.078 & 588 & 0.020 & 0.019 & 212 & 0.023 & 0.014 & 0.010 \\
\hline 800 & 11.965 & 1.142 & 9.470 & 14.140 & 588 & 11.805 & 1.171 & 212 & 12.409 & 0.923 & 0.000 \\
\hline 550 & 0.841 & 0.079 & 0.540 & 0.987 & 364 & 0.834 & 0.088 & 186 & 0.853 & 0.582 & 0.008 \\
\hline 800 & 0.148 & 0.018 & 0.103 & 0.198 & 588 & 0.147 & 0.019 & 212 & 0.151 & 0.014 & 0.005 \\
\hline 800 & 0.247 & 0.032 & 0.184 & 0.341 & 588 & 0.252 & 0.033 & 212 & 0.235 & 0.027 & 0.000 \\
\hline 800 & 0.690 & 0.354 & 0.039 & 0.980 & 588 & 0.685 & 0.374 & 212 & 0.706 & 0.292 & 0.460 \\
\hline 650 & 3.231 & 6.106 & 0.000 & 25.000 & 528 & 2.808 & 6.077 & 122 & 5.062 & 5.916 & 0.000 \\
\hline 650 & 0.014 & 0.010 & 0.000 & 0.039 & 528 & 0.014 & 0.105 & 122 & 0.015 & 0.001 & 0.302 \\
\hline 650 & 0.677 & 0.468 & 0.000 & 1.000 & 528 & 0.625 & 0.485 & 122 & 0.902 & 0.299 & 0.000 \\
\hline 700 & -0.158 & 0.484 & -4.323 & 5.900 & 496 & -0.141 & 0.502 & 204 & -0.199 & 0.436 & 0.155 \\
\hline 3,329 & 8.472 & 0.351 & 6.955 & 9.562 & 2,500 & 8.414 & 0.356 & 829 & 8.648 & 0.264 & 0.000 \\
\hline 3,329 & 8.472 & 0.345 & 7.035 & 9.781 & 2,500 & 8.653 & 0.347 & 829 & 8.653 & 0.266 & 0.000 \\
\hline 3,329 & 8.538 & 0.614 & 5.299 & 10.148 & 2,500 & 8.496 & 0.634 & 829 & 8.665 & 0.529 & 0.000 \\
\hline 3,329 & 7.975 & 578.274 & $-6,990.880$ & $3,465.496$ & 2,500 & 21.492 & 551.374 & 829 & -32.791 & 651.384 & 0.019 \\
\hline
\end{tabular}

- For reasons of clarity statistics for the nine spending categories are not shown. ---

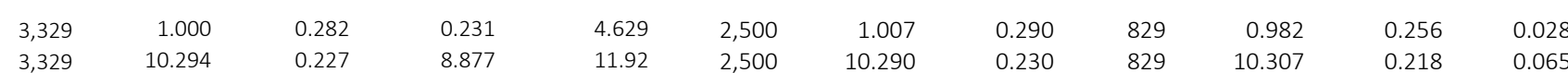

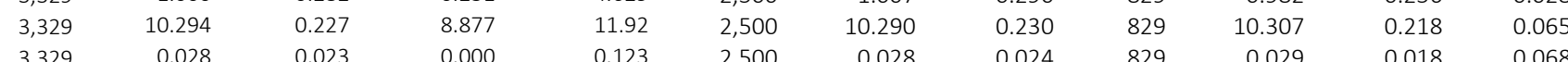

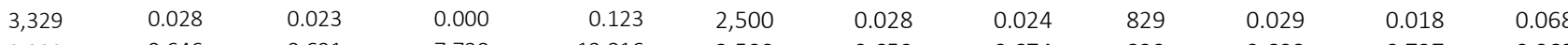

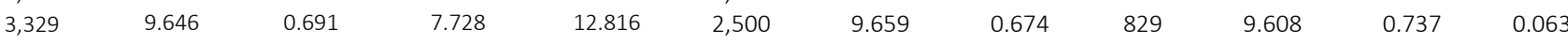

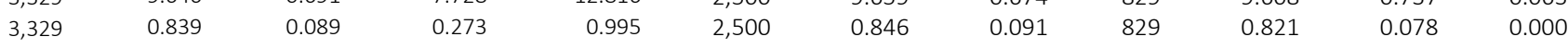

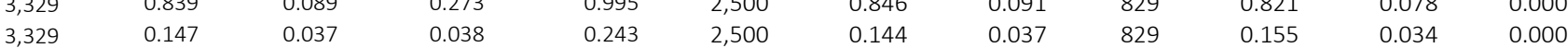

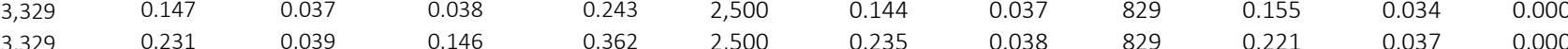

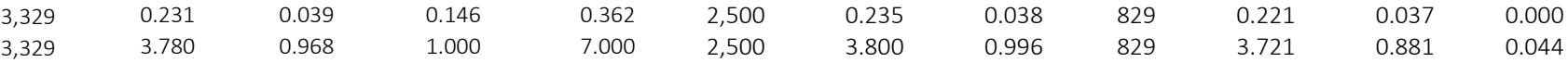

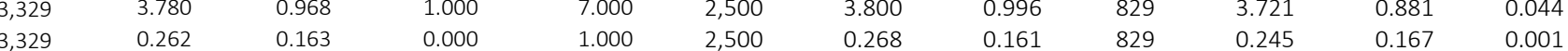
onding canton implements a debt brake. 2) Two-tailed p-value for the difference in means between the two groups of municipalities. The null hypothesis being that the difference between the means is zero. 
Table A.2 Definition and source of variables*

\begin{tabular}{|c|c|c|c|c|c|}
\hline & Level & Cantons & Period & Source & Description \\
\hline Dependent variables & SAMPLE 1 & & & & \\
\hline Expenditure per capita (log) & Cantonal aggregated local data & 25 & 1980-2011 & Swiss Federal Finance Administration & Total expenditure per capita, adjusted for double counting. \\
\hline Revenue per capita (log) & Cantonal aggregated local data & 25 & 1980-2011 & Swiss Federal Finance Administration & Total revenue per capita, adjusted for double counting. \\
\hline Debt per capita (log) & Cantonal aggregated local data & 25 & 1990-2011 & Swiss Federal Finance Administration & Total debt per capita, adjusted for double counting. \\
\hline Deficit per capita & Cantonal aggregated local data & 25 & 1980-2011 & Swiss Federal Finance Administration & Total revenues less total expenditures. A fiscal deficit is, thus, indicated by a positive and a surplus by a negative sign. \\
\hline Expenditure decentralization & $\mathrm{n} / \mathrm{a}$ & 25 & $1980-2011$ & Own calculation & Total expenditure of all municipalities in a canton divided by the sum of local and cantonal spending in that canton. \\
\hline Revenue decentralization & $\mathrm{n} / \mathrm{a}$ & 25 & 1980-2011 & Own calculation & Total revenue of all municipalities in a canton divided by the sum of local and cantonal revenues in that canton. \\
\hline Spending categories per capita (log) & Cantonal aggregated local data & 25 & 1990-2011 & Swiss Federal Finance Administration & $\begin{array}{l}\text { Nine spending categories: Administration, Security, Education, Culture and recreation, Health care, Environment, Social welfare, Transportation } \\
\text { and Others. Others includes expenditures on the economy and finances and taxes and Transportation includes communication. }\end{array}$ \\
\hline \multicolumn{6}{|r|}{ 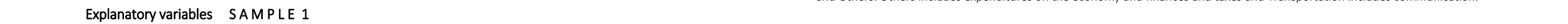 } \\
\hline Debt brake dummy ${ }^{\sharp}$ & Cantonal & 25 & 1980-2011 & Feld et al. (2013) and own research & Dummy which equals one if a canton is legally constrained by a debt brake and zero otherwise. \\
\hline Debt brake index" & Cantonal & 25 & 1980-2011 & Feld et al. (2013) and own research & Measures the stringency of cantonal debt brakes on a scale between zero and three. \\
\hline Relative income & Cantonal & 25 & 1980-2011 & Own calculation & Cantonal taxable income per capita as share of average cantonal taxable income per capita of all municipalities in the sample. \\
\hline Income per capita (log) & Cantonal & 25 & 1980-2011 & Swiss Federal Finance Administration & See note (1). \\
\hline Unemployment rate & Cantonal & 25 & 1980-2011 & Swiss Federal Statistical Office & \\
\hline Population (log) & Cantonal & 25 & $1980-2011$ & Swiss Federal Statistical Office & Mean residential population. \\
\hline Share own revenue & Cantonal aggregated data & 25 & 1990-2011 & Swiss Federal Finance Administration & $\begin{array}{l}\text { Share of own revenues of all municipalities within a canton on total revenues in the same municipalities. Own revenues are calculated by } \\
\text { subtracting total transfer receipts from total revenues. }\end{array}$ \\
\hline Share old & Cantonal & 25 & 1980-2011 & Own calculation & Share of population aged 65 and above according to the midyear (2011 end of the year) permanent residential population. \\
\hline Share young & Cantonal & 25 & 1980-2011 & Own calculation & Share of population aged 20 and below according to the midyear ( 2011 end of the year) permanent residential population. \\
\hline Share German speaking" & Cantonal & 25 & 1980-2011 & Swiss Federal Statistical Office & Share of population speaking German (data changes only once in ten years). \\
\hline Spending threshold for referenda & Cantonal & 25 & 1980-2005 & Feld et al. (2013) & Expenditure thresholds (in million Swiss Francs) that trigger mandatory referenda if exceeded. It equals zero if no mandatory referenda is in place. \\
\hline Signature requirement for initiatives & Cantonal & 25 & 1980-2005 & Feld et al. (2013) & Number of signatures per capita required launching a statutory initiative process. \\
\hline Mandatory referendum dummy & Cantonal & 25 & 1980-2005 & Feld et al. (2013) & Dummy that equals one if spending projects require an approval by the majority of voters and zero otherwise. \\
\hline Fiscal shock per capita & Cantonal & 25 & 1984-2011 & Own calculation & $\begin{array}{l}\text { Measured in million Swiss Francs. Calculation based on realized and forecasted current cantonal income and expenses as provided by Luechinger } \\
\text { and Schaltegger (2013) and Conference of Cantonal Finance Ministers. }\end{array}$ \\
\hline Dependent variables & SAMPLE 2 & & & & \\
\hline Expenditure per capita (log) & Local & 24 & 1982-2007 & Yearbooks Swiss Association of Cities & Total expenditure per capita. \\
\hline Revenue per capita (log) & Local & 24 & 1982-2007 & Yearbooks Swiss Association of Cities & Total revenue per capita. \\
\hline Debt per capita (log) & Local & 24 & 1982-2007 & Yearbooks Swiss Association of Cities & Sum of current liabilities, short-, medium- and long-term debts and liabilities for special accounts. \\
\hline Deficit per capita & Local & 24 & $1982-2007$ & Yearbooks Swiss Association of Cities & Total revenues less total expenditures. A fiscal deficit is, thus, indicated by a positive and a surplus by a negative sign. \\
\hline Spending categories per capita (log) & Local & 24 & 1982-2007 & Yearbooks Swiss Association of Cities & $\begin{array}{l}\text { The nine categories are: Administrration, Security, Education, Culture and recreation, Health care, Environment, Social welfare, Transportation } \\
\text { and Others. Security indicates expenditures on judicature, police and fire department. Transportation includes transportation and energy until } \\
1989 \text { and only transportation thereafter. }\end{array}$ \\
\hline \multicolumn{6}{|r|}{1989 dan oniy transportation thereatrer. } \\
\hline Relative income & Local & 24 & 1982-2007 & Own calculation & Local taxable income per capita as share of average local taxable income per capita of all municipalities in the sample. \\
\hline Income per capita (log) & Local & 24 & 1982-2007 & Swiss Federal Finance Administration & See note (1). \\
\hline Unemployment rate & Local & 24 & $1982-2007$ & Yearbooks Swiss Association of Cities & \\
\hline Population (log) & Local & 24 & 1982-2007 & Yearbooks Swiss Association of Cities & \\
\hline Share own revenue & Local & 24 & 1982-2007 & Yearbooks Swiss Association of Cities & 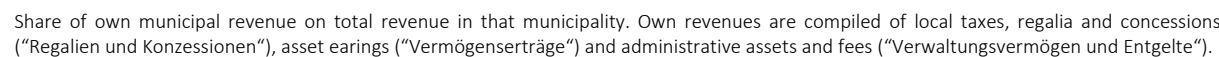 \\
\hline Share old & Local & 24 & 1982-2007 & Yearbooks Swiss Association of Cities & Share of population aged 65 and above (data changes only once in ten years in most cases). \\
\hline Share young & Local & 24 & 1982-2007 & Yearbooks Swiss Association of Cities & Share of population aged 25 and below (data changes only once in ten years in most cases). \\
\hline Ideology government & Local & 24 & 1982-2007 & Yearbooks Swiss Association of Cities & Share of left wing parties in municipal executive. See also note (2). \\
\hline Coalition government & Local & 24 & $1982-2007$ & Yearbooks Swiss Association of Cities & Number of different political parties in municipal executive. \\
\hline
\end{tabular}

Note: * All monetary variables are deflated to the year 2000, based on the Swiss consumer price index. "indicates that variable is employed in both samples. (1) Taxable income of natural persons, including special cases (e.g., in-between and temporary assessment, flat tax, residents with overseas income and foreigner with according to same year's income, providing us with annual income data. Due to the transition from praenumerando to postnumerando taxation, income data is missing for two consecutive years in most cases. Missing income data was derived through interpolation. Data for 2011 was calculated by extrapolation. (2) The according to same vear's income, providing us with annual income data. Due to the transition from praenumerando to postnumerando taxation, income data is missing for two consecutive years in most cases. Missing income data was dervived through interpolation. D D
following Swiss parties are considered as left wing orientated: Green Party (GPS), Evangelical People's Party (EVP), Social Democratic Party (SPS), SWiss Party of Labour (PDA) and Progressive Organizations of Switzerland (POCH). See Swiss Federal Chancellery (2007, 2011). 
Table A.3 Baseline regression of sample 1: Expenditure categories in (almost) all municipalities, 1990-2011

\begin{tabular}{|c|c|c|c|c|c|c|c|c|c|c|c|c|c|c|c|c|c|c|}
\hline & \multicolumn{2}{|c|}{ Admin } & \multicolumn{2}{|c|}{ Security } & \multicolumn{2}{|c|}{ Education } & \multicolumn{2}{|c|}{$\begin{array}{l}\text { Culture and } \\
\text { recreation }\end{array}$} & \multicolumn{2}{|c|}{ Health care } & \multicolumn{2}{|c|}{ Environment } & \multicolumn{2}{|c|}{ Social Welfare } & \multicolumn{2}{|c|}{ Transportation } & \multicolumn{2}{|c|}{ Others } \\
\hline Debt brake & $\begin{array}{r}0.032 \\
(1.171) \\
{[0.271]}\end{array}$ & & $\begin{array}{r}0.013 \\
(0.343) \\
{[0.727]}\end{array}$ & & $\begin{array}{r}-0.104 \\
(-1.176) \\
{[0.304]}\end{array}$ & & $\begin{array}{r}-0.014 \\
(-0.226) \\
{[0.837]}\end{array}$ & & $\begin{array}{r}0.243 \\
(0.681) \\
{[0.595]}\end{array}$ & & $\begin{array}{r}0.062 \\
(1.356) \\
{[0.236]}\end{array}$ & & $\begin{array}{c}0.032 \\
(0.342) \\
{[0.825]}\end{array}$ & & $\begin{array}{c}-0.064^{*} \\
(-1.963) \\
{[0.074]}\end{array}$ & & $\begin{array}{r}0.044 \\
(0.563) \\
{[0.615]}\end{array}$ & \\
\hline \multirow[t]{2}{*}{$\begin{array}{l}\text { Fiscal } \\
\text { index }\end{array}$} & & $\begin{array}{r}0.012 \\
(0.814)\end{array}$ & & $\begin{array}{r}0.002 \\
(0.071)\end{array}$ & & $\begin{array}{r}-0.049 \\
(-1.071)\end{array}$ & & $\begin{array}{r}-0.004 \\
(-0.120)\end{array}$ & & $\begin{array}{r}0.156 \\
(0.859)\end{array}$ & & $\begin{array}{l}0.046^{*} \\
(2.007)\end{array}$ & & $\begin{array}{r}0.024 \\
(0.483)\end{array}$ & & $\begin{array}{r}-0.045 * * \\
(-2.718)\end{array}$ & & $\begin{array}{r}0.007 \\
(0.169)\end{array}$ \\
\hline & & {$[0.448]$} & & [0.965] & & {$[0.456]$} & & {$[0.929]$} & & {$[0.428]$} & & [0.084] & & [0.623] & & {$[0.020]$} & & [0.871] \\
\hline Controls & Yes & Yes & Yes & Yes & Yes & Yes & Yes & Yes & Yes & Yes & Yes & Yes & Yes & Yes & Yes & Yes & Yes & Yes \\
\hline Two-way FE & Yes & Yes & Yes & Yes & Yes & Yes & Yes & Yes & Yes & Yes & Yes & Yes & Yes & Yes & Yes & Yes & Yes & Yes \\
\hline Adj. R2 & 0.15 & 0.15 & 0.26 & 0.26 & 0.16 & 0.15 & 0.08 & 0.08 & 0.40 & 0.40 & 0.13 & 0.14 & 0.20 & 0.20 & 0.28 & 0.29 & 0.35 & 0.35 \\
\hline $\mathrm{N}$ & 550 & 550 & 550 & 550 & 550 & 550 & 550 & 550 & 549 & 549 & 550 & 550 & 550 & 550 & 550 & 550 & 550 & 550 \\
\hline Cluster & 25 & 25 & 25 & 25 & 25 & 25 & 25 & 25 & 25 & 25 & 25 & 25 & 25 & 25 & 25 & 25 & 25 & 25 \\
\hline Wald test: FE & $197^{* * *}$ & $234^{* * *}$ & $69 * * *$ & $56^{* * *}$ & $37 * * *$ & $207 * * *$ & $535^{* * *}$ & $818^{* * *}$ & $2,220 * * *$ & $2,745^{* * *}$ & $2,280 * * *$ & $4,998 * * *$ & $41,500 * * *$ & $96,249 * * *$ & $4,189 * * *$ & $55^{* * *}$ & $124 * * *$ & $450^{* * *}$ \\
\hline
\end{tabular}

Note: Same controls included as in the baseline regression of sample 1 (Table 3). The numbers in parentheses indicate the estimated t-statistics for standard errors that are adjusted for clustering at the cantonal level and corrected for heteroscedasticity. These values are used to determine statistical significance: ${ }^{*} \mathrm{p}<0.1$ (significance at the $10 \%$ level), ${ }^{* *}$ p $<0.05$ (significance at the $5 \%$ level), and $*^{* * *}<<0.01$ (significance at the $1 \%$ level). The numbers in brackets indicate the estimated p-values using the wild-cluster bootstrap-t procedure. The Wald test has the null hypothesis that the fixed effects are jointly equal to zero. For the Wald tests, we report test statistics based on regressions with cluster-robust standard errors.

Table A.4 Baseline regression of sample 2: Expenditure categories in 139 large municipalities, 1982-2007

\begin{tabular}{|c|c|c|c|c|c|c|c|c|c|c|c|c|c|c|c|c|c|c|}
\hline & \multicolumn{2}{|c|}{ Admin } & \multicolumn{2}{|c|}{ Security } & \multicolumn{2}{|c|}{ Education } & \multicolumn{2}{|c|}{$\begin{array}{l}\text { Culture and } \\
\text { recreation }\end{array}$} & \multicolumn{2}{|c|}{ Health care } & \multicolumn{2}{|c|}{ Environment } & \multicolumn{2}{|c|}{ Social Welfare } & \multicolumn{2}{|c|}{ Transportation } & \multicolumn{2}{|c|}{ Others } \\
\hline Debt brake & $\begin{array}{r}-0.055 \\
\{-2.821\} \\
{[0.292]}\end{array}$ & & $\begin{array}{r}-0.118^{*} \\
\{-4.473\} \\
{[0.080}\end{array}$ & & $\left\{\begin{array}{c}-0.142 \\
\{-6.268\} \\
{[0.569]}\end{array}\right.$ & & $\begin{array}{r}0.001 \\
\{0.014\} \\
{[0.921]}\end{array}$ & & $\begin{array}{r}-0.381 \\
\{-5.633\} \\
{[0.460]}\end{array}$ & & $\begin{array}{r}-0.058 \\
\{-2.096\} \\
{[0.450]}\end{array}$ & & $\begin{array}{r}-0.030 \\
\{-1.099\} \\
{[0.811]}\end{array}$ & & $\begin{array}{r}0.003 \\
\{0.104\} \\
{[0.973]}\end{array}$ & & $\begin{array}{r}0.043 \\
\{1.250\} \\
{[0.478]}\end{array}$ & \\
\hline Fiscal rule index & & $\begin{array}{r}-0.027 \\
\{-2.215\} \\
{[0.476]}\end{array}$ & & $\begin{array}{r}-0.053 \\
\{-3.284\} \\
{[0.144]}\end{array}$ & & $\begin{array}{r}-0.123 \\
\{-8.918\} \\
{[0.687]}\end{array}$ & & $\begin{array}{r}-0.037 \\
\{-1.319\} \\
{[0.667]}\end{array}$ & & $\begin{array}{r}-0.315 \\
\{-7.641\} \\
{[0.593]}\end{array}$ & & $\begin{array}{r}-0.021 \\
\{-1.218\} \\
{[0.585]}\end{array}$ & & $\begin{array}{r}-0.016 \\
\{-0.988\} \\
{[0.711]}\end{array}$ & & $\begin{array}{r}-0.001 \\
\{-0.070\} \\
{[0.965]}\end{array}$ & & $\begin{array}{r}0.017 \\
\{0.793\} \\
{[0.741]}\end{array}$ \\
\hline Controls & Yes & Yes & Yes & Yes & Yes & Yes & Yes & Yes & Yes & Yes & Yes & Yes & Yes & Yes & Yes & Yes & Yes & Yes \\
\hline Two-way FE & Yes & Yes & Yes & Yes & Yes & Yes & Yes & Yes & Yes & Yes & Yes & Yes & Yes & Yes & Yes & Yes & Yes & Yes \\
\hline $\begin{array}{l}\text { Adj. R2 } \\
\mathrm{N}\end{array}$ & $\begin{array}{r}0.28 \\
3329\end{array}$ & $\begin{array}{r}0.28 \\
3329\end{array}$ & $\begin{array}{r}0.48 \\
3329\end{array}$ & $\begin{array}{r}0.48 \\
3329\end{array}$ & $\begin{array}{r}0.14 \\
3329\end{array}$ & $\begin{array}{r}0.15 \\
3329\end{array}$ & $\begin{array}{r}0.57 \\
3329\end{array}$ & $\begin{array}{r}0.57 \\
3329\end{array}$ & $\begin{array}{r}0.12 \\
3169\end{array}$ & $\begin{array}{r}0.13 \\
3169\end{array}$ & $\begin{array}{r}0.10 \\
3329\end{array}$ & $\begin{array}{r}0.10 \\
3329\end{array}$ & $\begin{array}{r}0.51 \\
3329\end{array}$ & $\begin{array}{r}0.51 \\
3329\end{array}$ & $\begin{array}{r}0.22 \\
3329\end{array}$ & $\begin{array}{r}0.22 \\
3329\end{array}$ & $\begin{array}{r}0.42 \\
3329\end{array}$ & $\begin{array}{r}0.42 \\
3329\end{array}$ \\
\hline Wald test: FE & $25 * * *$ & $26 * * *$ & $84 * * *$ & $85 * * *$ & $85 * * *$ & $86 * * *$ & $31^{* * *}$ & $30 * * *$ & $65^{* * *}$ & $66^{* * *}$ & $33 * * *$ & $33 * * *$ & $89 * * *$ & $89 * * *$ & $32 * * *$ & $33 * * *$ & $42^{* * *}$ & $42 * * *$ \\
\hline
\end{tabular}

Note: Same controls included as in the baseline regression of sample 2 (Table 4). The numbers in brackets indicate the estimated p-values using wild-cluster bootstrap-t procedure. These values are used to determine statistical

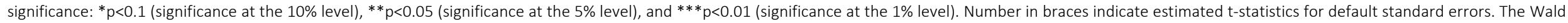
test has the null hypothesis that the fixed effects are jointly equal to zero. For the Wald tests, we report test statistics based on regressions with default standard errors. 
Figure A.1 Development of local finances per capita in the control and treatment groups

Sample 1: Public debt per capita

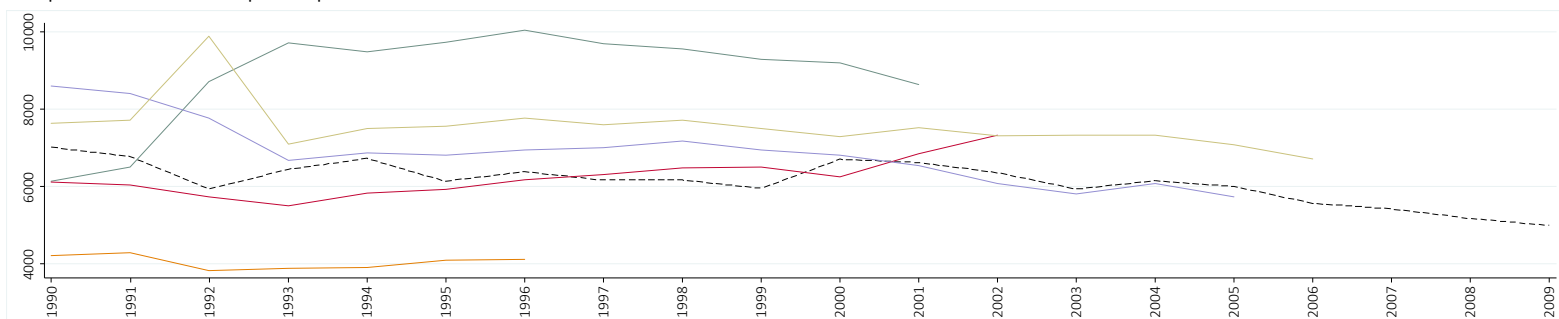

Sample 1: Revenues per capita

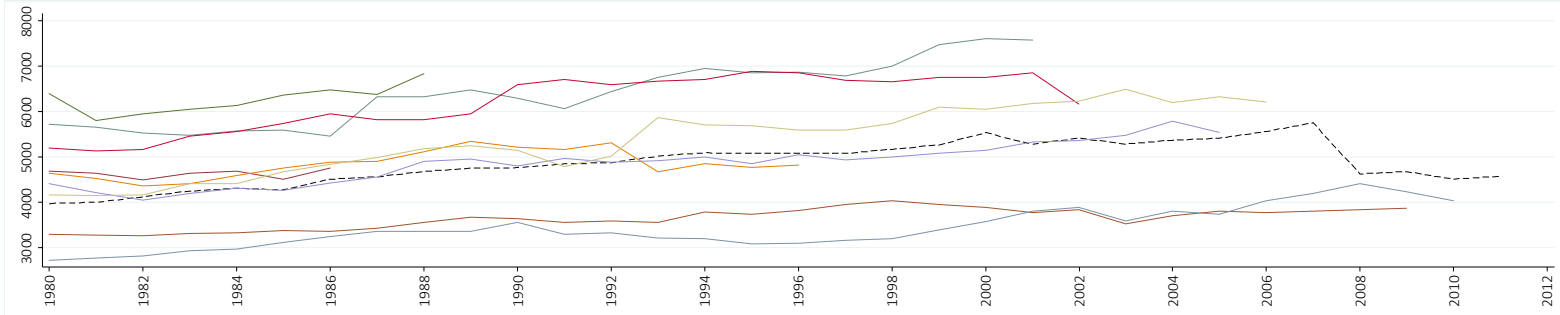

Sample 1: Expenditure per capita

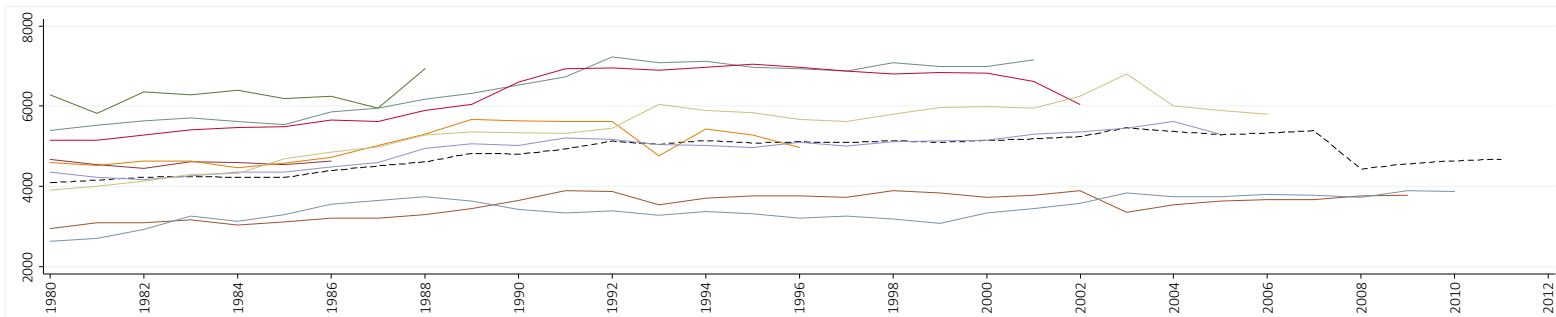

Sample 2: Public debt per capita

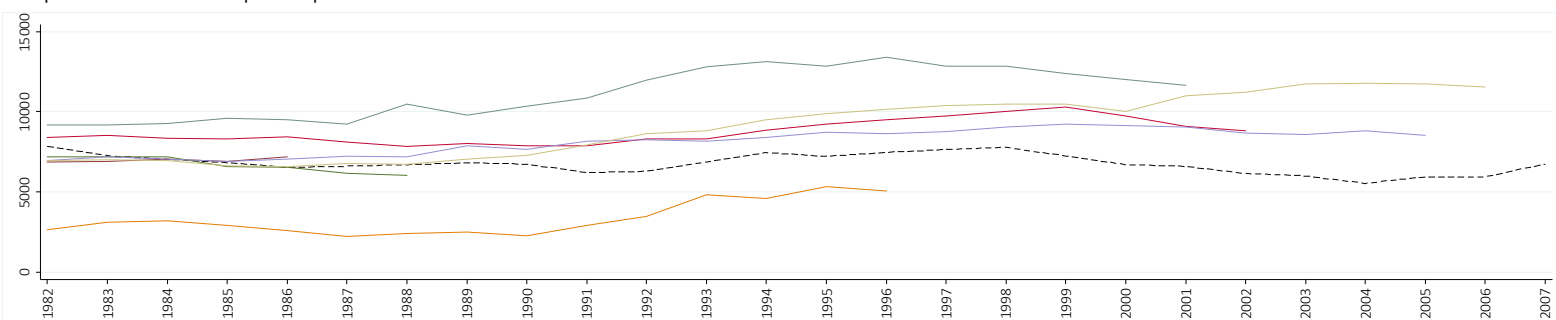

Sample 2: Revenues per capita

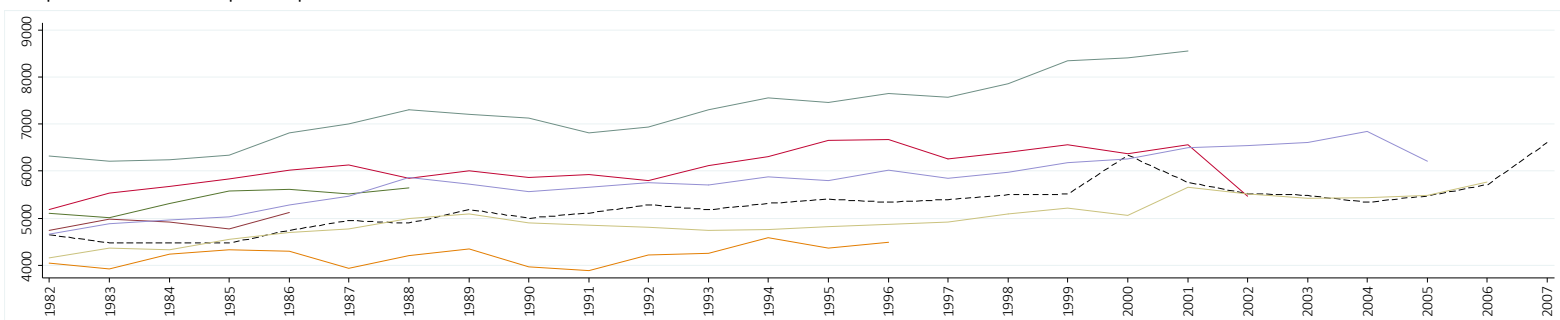

Sample 2: Expenditure per capita

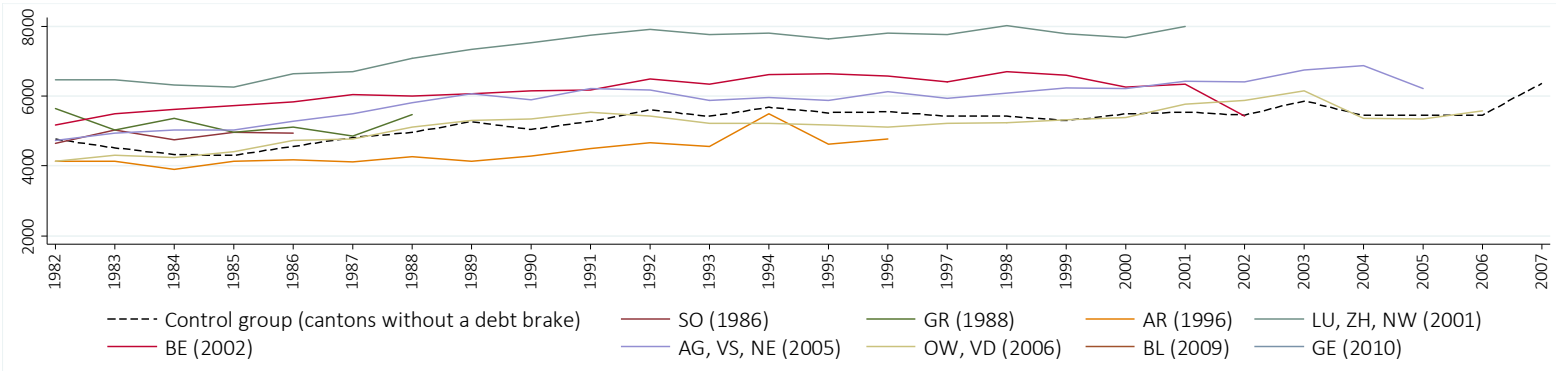

Note: For reasons of clarity and comprehensibility, data of the 139 municipalities (sample 2) is aggregated at the level of the corresponding canton. The control group includes municipalities that are located in cantons without a debt brake during the whole period 1980-2010 (sample 1) and 1982-2010 (sample 2), respectively. Since the treatment (debt brake introduction) took place at different points of time, various treatment groups are depicted. The development of local finances in the treatment groups is only shown prior to treatment. All values are in real terms. 
Table A.5 Sample 1: Pre-estimation test on cross-sectional dependence

\begin{tabular}{lrrrrr}
\hline Dependent variable & CD-test & p-value & $\begin{array}{r}\text { Average correlation } \\
\text { coefficient }\end{array}$ & $\begin{array}{r}\text { Absolute correlation } \\
\text { coefficient }\end{array}$ & $\begin{array}{r}\text { Cross-sectional } \\
\text { dependence? }\end{array}$ \\
\hline Expenditures per capita (log) & 17.29 & 0.000 & 0.213 & 0.372 & $\checkmark$ \\
Revenues per capita (log) & 31.23 & 0.000 & 0.384 & 0.448 & $\checkmark$ \\
Debt per capita (log) & 27.69 & 0.000 & 0.341 & 0.457 & $\checkmark$ \\
Deficit per capita & 27.19 & 0.000 & 0.335 & 0.360 & $\checkmark$ \\
Expenditure decentralization & 56.00 & 0.000 & 0.572 & 0.578 & $\checkmark$ \\
Revenue decentralization & 53.93 & 0.000 & 0.550 & 0.563 & $\checkmark$ \\
Expenditures on administration (log) & -0.36 & 0.720 & -0.004 & 0.282 & $\checkmark$ \\
Expenditures on security (log) & 14.96 & 0.000 & 0.184 & 0.345 & $\checkmark$ \\
Expenditures on education (log) & 10.70 & 0.000 & 0.132 & 0.363 & $\checkmark$ \\
Expenditures on culture (log) & 11.41 & 0.000 & 0.474 & 0.267 & $\checkmark$ \\
Expenditures on health care (log) & 38.46 & 0.000 & 0.213 & 0.581 & $\checkmark$ \\
Expenditures on social welfare (log) & 17.30 & 0.000 & 0.205 & 0.442 & $\checkmark$ \\
Expenditures on transportation (log) & 16.61 & 0.000 & 0.060 & 0.316 & $\checkmark$ \\
Expenditures on environment (log) & 4.93 & 0.000 & 0.239 & 0.302 & $\checkmark$ \\
Expenditures on others (log) & 19.40 & 0.000 & & 0.407 & $\checkmark$ \\
\hline
\end{tabular}

Note: We report the average and absolute correlation coefficient across N x (N-1) pairs of correlation. CD presents the Pesaran (2004) crosssection dependence statistic that is distributed standard normal and tests the null hypothesis of cross-section independence of error terms. We use the Stata routine xtcd.

Table A.6 Sample 1: Effect of fiscal rules on Local finances 1980-2005, cantonal direct democracy

\begin{tabular}{|c|c|c|c|c|c|c|c|c|}
\hline & Expenditure & & Revenue & & Debt & & Deficit & \\
\hline Debt brake & $\begin{array}{r}-0.043 \\
(-1.626) \\
{[0.206]}\end{array}$ & & $\begin{array}{r}-0.036 \\
(-1.232) \\
{[0.298]}\end{array}$ & & $\begin{array}{l}0.113^{*} \\
(1.829) \\
{[0.100]}\end{array}$ & & $\begin{array}{c}-25.136 \\
(-0.625) \\
{[0.466]}\end{array}$ & \\
\hline Fiscal rule index & & $\begin{array}{r}-0.020 \\
(-1.129) \\
{[0.310]}\end{array}$ & & $\begin{array}{r}-0.015 \\
(-0.734) \\
{[0.532]}\end{array}$ & & $\begin{array}{l}0.074 * \\
(1.980) \\
{[0.174]}\end{array}$ & & $\begin{array}{r}-19.148 \\
(-1.023) \\
{[0.294]}\end{array}$ \\
\hline $\begin{array}{l}\text { Spending } \\
\text { threshold }\end{array}$ & $\begin{array}{r}0.002 \\
(0.637) \\
{[0.583]}\end{array}$ & $\begin{array}{r}0.002 \\
(0.972) \\
{[0.394]}\end{array}$ & $\begin{array}{r}0.002 \\
(0.610) \\
{[0.548]}\end{array}$ & $\begin{array}{r}0.002 \\
(0.927) \\
{[0.396]}\end{array}$ & $\begin{array}{r}-0.006 \\
(-1.029) \\
{[0.328]}\end{array}$ & $\begin{array}{r}-0.007 \\
(-1.338) \\
{[0.234]}\end{array}$ & $\begin{array}{r}7.213 \\
(1.061) \\
{[0.607]}\end{array}$ & $\begin{array}{r}7.399 \\
(1.142) \\
{[0.555]}\end{array}$ \\
\hline $\begin{array}{l}\text { Signature } \\
\text { requirement }\end{array}$ & $\begin{array}{r}-9.568^{* * *} \\
(-2.902) \\
{[0.032]}\end{array}$ & $\begin{array}{r}-9.621^{* * *} \\
(-2.863) \\
{[0.038]}\end{array}$ & $\begin{array}{r}-8.221^{* * *} \\
(-2.855) \\
{[0.032]}\end{array}$ & $\begin{array}{r}-8.312^{* * * *} \\
(-2.855) \\
{[0.026]}\end{array}$ & $\begin{array}{r}-7.061 \\
(-0.982) \\
{[0.418]}\end{array}$ & $\begin{array}{r}-7.096 \\
(-1.004) \\
{[0.420]}\end{array}$ & $\begin{array}{r}-4^{\prime} 587.247 \\
(-0.556) \\
{[0.649]}\end{array}$ & $\begin{array}{r}-4^{\prime} 417.276 \\
(-0.526) \\
{[0.701]}\end{array}$ \\
\hline $\begin{array}{l}\text { Mandatory } \\
\text { referendum }\end{array}$ & $\begin{array}{r}-0.097^{*} \\
(-2.064) \\
{[0.340]}\end{array}$ & $\begin{array}{r}-0.103^{* *} \\
(-2.112) \\
{[0.252]}\end{array}$ & $\begin{array}{r}-0.085^{*} \\
(-1.934) \\
{[0.212]}\end{array}$ & $\begin{array}{r}-0.089 * \\
(-1.991) \\
{[0.192]}\end{array}$ & $\begin{array}{r}0.045 \\
(0.483) \\
{[0.671]}\end{array}$ & $\begin{array}{r}0.055 \\
(0.602) \\
{[0.637]}\end{array}$ & $\begin{array}{r}-92.679 \\
(-0.739) \\
{[0.855]}\end{array}$ & $\begin{array}{r}-93.634 \\
(-0.740) \\
{[0.887]}\end{array}$ \\
\hline $\begin{array}{l}\text { Further controls } \\
\text { Two-way FE }\end{array}$ & $\begin{array}{l}\text { Yes } \\
\text { Yes }\end{array}$ & $\begin{array}{l}\text { Yes } \\
\text { Yes }\end{array}$ & $\begin{array}{l}\text { Yes } \\
\text { Yes }\end{array}$ & $\begin{array}{l}\text { Yes } \\
\text { Yes }\end{array}$ & $\begin{array}{l}\text { Yes } \\
\text { Yes }\end{array}$ & $\begin{array}{l}\text { Yes } \\
\text { Yes }\end{array}$ & $\begin{array}{l}\text { Yes } \\
\text { Yes }\end{array}$ & $\begin{array}{l}\text { Yes } \\
\text { Yes }\end{array}$ \\
\hline Adj. R2 & 0.70 & 0.69 & 0.66 & 0.66 & 0.32 & 0.32 & 0.23 & $\begin{array}{r}0.23 \\
650\end{array}$ \\
\hline Cluster & $\begin{array}{r}650 \\
25\end{array}$ & $\begin{array}{r}650 \\
25\end{array}$ & $\begin{array}{r}650 \\
25\end{array}$ & $\begin{array}{r}650 \\
25\end{array}$ & $\begin{array}{r}400 \\
25\end{array}$ & $\begin{array}{r}400 \\
25\end{array}$ & $\begin{array}{r}650 \\
25\end{array}$ & $\begin{array}{r}850 \\
25\end{array}$ \\
\hline Wald test: FE & $1,236.01^{* * *}$ & $125.23 * * *$ & $152.58 * * *$ & $732.18^{* * *}$ & $1,371.26^{* * *}$ & $2,405.36^{* * *}$ & $15.18^{* * *}$ & $17.70^{* * *}$ \\
\hline
\end{tabular}

Note: Besides the controls shown, we employ all controls as in the corresponding baseline regression of sample 1 (Table 3). Due to data limitations, public debt is only analyzed during the years 1990-2009. Canton and year fixed effects are included. The numbers in parentheses indicate the estimated t-statistics for standard errors that are adjusted for clustering at the cantonal level and corrected for heteroscedasticity. These values are used to determine statistical significance: ${ }^{*} p<0.1$ (significance at the $10 \%$ level), ${ }^{* *} p<0.05$ (significance at the $5 \%$ level), and ${ }^{* * *} \mathrm{p}<0.01$ (significance at the $1 \%$ level). The numbers in brackets indicate the estimated $\mathrm{p}$-values using the wild-cluster bootstrap-t procedure. The Wald test has the null hypothesis that the fixed effects are jointly equal to zero. For the Wald tests, we report test statistics based on regressions with cluster-robust standard errors. 
Table A.7 Sample 1: Effect of fiscal rules on decentralization 1980-2011, cantonal direct democracy

\begin{tabular}{lrr|rr}
\hline & Expenditure decentralization & Revenue decentralization & \\
\hline Debt brake & $-0.028^{* * *}$ & & $-0.035^{* * *}$ & $(-3.413)$ \\
& $(-3.299)$ & & {$[0.012]$} & $-0.017^{* * *}$ \\
& {$[0.006]$} & $-0.014^{* *}$ & & $(-2.927)$ \\
Fiscal rule index & & $(-2.710)$ & & {$[0.012]$} \\
& & {$[0.038]$} & & $-0.002^{*}$ \\
& & $-0.002^{* *}$ & $-0.003^{* *}$ & $(-1.993)$ \\
Spending threshold & $-0.003^{* *}$ & $(-2.212)$ & $(-2.545)$ & {$[0.084]$} \\
& $(-2.729)$ & {$[0.056]$} & {$[0.052]$} & -0.462 \\
& {$[0.018]$} & -0.808 & -0.443 & $(-0.323)$ \\
Signature requirement & -0.786 & $(-0.558)$ & $(-0.326)$ & {$[0.775]$} \\
& $(-0.568)$ & {$[0.607]$} & {$[0.777]$} & 0.017 \\
Mandatory referendum & {$[0.669]$} & 0.009 & 0.021 & $(0.715)$ \\
& 0.012 & $(0.392)$ & $(0.925)$ & {$[0.528]$} \\
& $(0.561)$ & {$[0.783]$} & {$[0.464]$} & Yes \\
Further controls & {$[0.651]$} & Yes & Yes & Yes \\
Two-way fixed effects & Yes & Yes & Yes & 0.42 \\
Adj. R2 & Yes & 0.50 & 0.44 & 650 \\
$N$ & 0.51 & 650 & 650 & 25 \\
Cluster & 650 & 25 & 25 & $87.05^{* * *}$ \\
Wald test: FE & 25 & $449.27 * * *$ & $151.81^{* * *}$ & \\
\hline
\end{tabular}

Note: Besides the controls shown, we employ all controls as in the corresponding baseline regression of sample 1 (Table 5). Canton and year fixed effects are included. The numbers in parentheses indicate the estimated t-statistics for standard errors that are adjusted for clustering at the cantonal level and corrected for heteroscedasticity. These values are used to determine statistical significance: ${ }^{*} \mathrm{p}<0.1$ (significance at the $10 \%$ level), ${ }^{* *} p<0.05$ (significance at the $5 \%$ level), and ${ }^{* * *} p<0.01$ (significance at the $1 \%$ level). The numbers in brackets indicate the estimated p-values using the wild-cluster bootstrap-t procedure. The Wald test has the null hypothesis that the fixed effects are jointly equal to zero. For the Wald tests, we report test statistics based on regressions with cluster-robust standard errors. 